\title{
Surface water quality in the Mastnik stream catchment area: The situation in the Czech countryside
}

\author{
LUBOŠ MRKVA, BOHUMÍR JANSKÝ
}

Charles University, Faculty of Science, Department of Physical Geography and Geoecology; Czechia, e-mail: mrkva.lub@gmail.com, jansky@natur.cuni.cz

ABSTRACT Despite major investments into the remediation of wastewater, and the reduction of fertilizers, the quality of small river surface water in agricultural and rural regions of Czechia is still very low. The Mastník stream flows through an agricultural area before combining with the Vltava river; a portion of the Mastník stream water inevitably terminates in the Slapy Reservoir. The quality of the water has been analyzed using data from indicator concentrations from both the Vltava River Basin Authority study profiles, and the author's monitoring profile. The data show that the steps that have been taken - primarily the construction of wastewater treatment plants - have led to a gradual improvement in the surface water quality by some parameters. Presently, a growing concentration of chlorophyll- $\alpha$ and a lack of dissolved oxygen are influencing the final quality of the water. In the case of the Mastník stream, it is particularly necessary to improve the remediation of wastewater from small households, and to reduce the impact of water erosion on agricultural soil.

KEY WORDS Mastnik River catchment area - point and non-point sources of pollution - agriculture - eutrofisation - Slapy reservoir

MRKVA, L., JANSKÝ, B. (2018): Surface water quality in the Mastnik stream catchment area: The situation in the Czech countryside. Geografie, 123, 4, 479-505.

Received February 2018, accepted November 2018.

(C) Česká geografická společnost, z. s., 2018 


\section{Introduction}

The surface water quality of small rivers in rural regions of Czechia is of particular concern today. The water quality in Czechia has been addressed in the past. The study by Janský $(1982,1983)$ showed very poor quality of surface water across the entire Labe catchment area. Investment into communal wastewater treatment facilities after 1990 have enabled significant improvement of water quality in most of our main rivers and their tributaries (Janský 2002; Langhammer, Kliment 2006). The construction of wastewater treatment plants at the level of small municipalities (under 2000 inhabitants), however, is at a standstill due to a lack of financing and financial support from the state is still insufficient. It is assumed that, contrarily to the main rivers, water quality in small watercourses has improved only slightly in the last several years or, more precisely, in some areas has deteriorated. The fact that water quality is related to the effects of climate change is of particular concern today (Bates et al. 2008), as also documented in many works addressing the issue that have been published in international journals. An example are the works published by the scientists of the Federal Institute of Hydrology, Germany (BfG, Koblenz). Here, the working group U2 predominantly studies larger rivers, such as the Rhine, Ems, Wesser and Elbe, but some works refer to smaller watercourses as well, for example the Saar River (Becker et al. 2010).

In the Czechia, primarily the upper parts of rivers and other waterbodies flow quickly out of Czech territory and, thus, it is necessary to pay particular attention to water resource management. Many important European rivers originate in Czech territory, and so the entire territory is designated a sensitive area (Punčochář, Desortová 2003). Pollution source restrictions have been at the centre of expert attention for many years. As a result, water quality has essentially improved, but problems remain in rural areas that are mostly agricultural in character. Agricultrure is responsible for the extensive degradation of water (Bouraoui, Grizzetti 2014). One of these watercourses is the Mastník stream, a tributary of the Vltava River. The Mastník stream is a typical representative of a small river with a predominance of agricultural land in its catchment area, similar to the Šlapanka stream (Judová, Janský 2005) and Cidlina River (Pivokonský, Benešová, Janský 2001). The issues of agriculture, hydrology and water quality have been summarised by Tlapák, Šálek, Legát (1992), and in Haygarth a Jarvis (2002). Trends in water quality have been followed by, for example Diamantini, Lutz et al. (2017) who analysed the general impacts and trends related to selected indicators in three European catchment areas. Their conclusions show an obvious increase in phosphate concentration, reflecting in change of agricultural area utilisation and population growth.

In the Mastník stream catchment area, a huge investment in communal wastewater treatment facilities was realised after 2004, yet despite that measure, the 
water quality in the Mastník stream catchment area is low. Diffuse pollution sources, such as rural sites and agriculture still, present a large problem, and are regarded as a general issue around the world. In Europe, this topic has been pursued by for example Taylor et al. (2016), Glendell et al. (2014) and in China by Zhou et al. (2016). Poor water quality in the catchment area manifests itself in the Mastník stream bay (influenced by surface water rise in the Slapy Reservoir), where a significant phytoplankton development has been observed during the growing season every year since 2002 (Mrkva 2013). Due to a surface water rise in the Slapy Reservoir, the water flux speed has been limited, and a significant growth of cyanobacteria and algae can be observed in the vegetative season. The aim of this work was, thus, to evaluate the quality of the surface water, to assess the anthropogenic pollution sources in the catchment area and to assess the impact of WWTPs on surface water quality.

\section{Natural conditions in the catchment area}

The Mastník stream catchment area belongs to the Lower Vltava catchment area. The stream flows through the Central Bohemian Uplands, forming a right-hand tributory to the Vltava. It runs into the Slapy Reservoir at approximately the $103^{\text {rd }}$ river kilometre (Fig. 1). The catchment area relief comprises rugged hilly areas

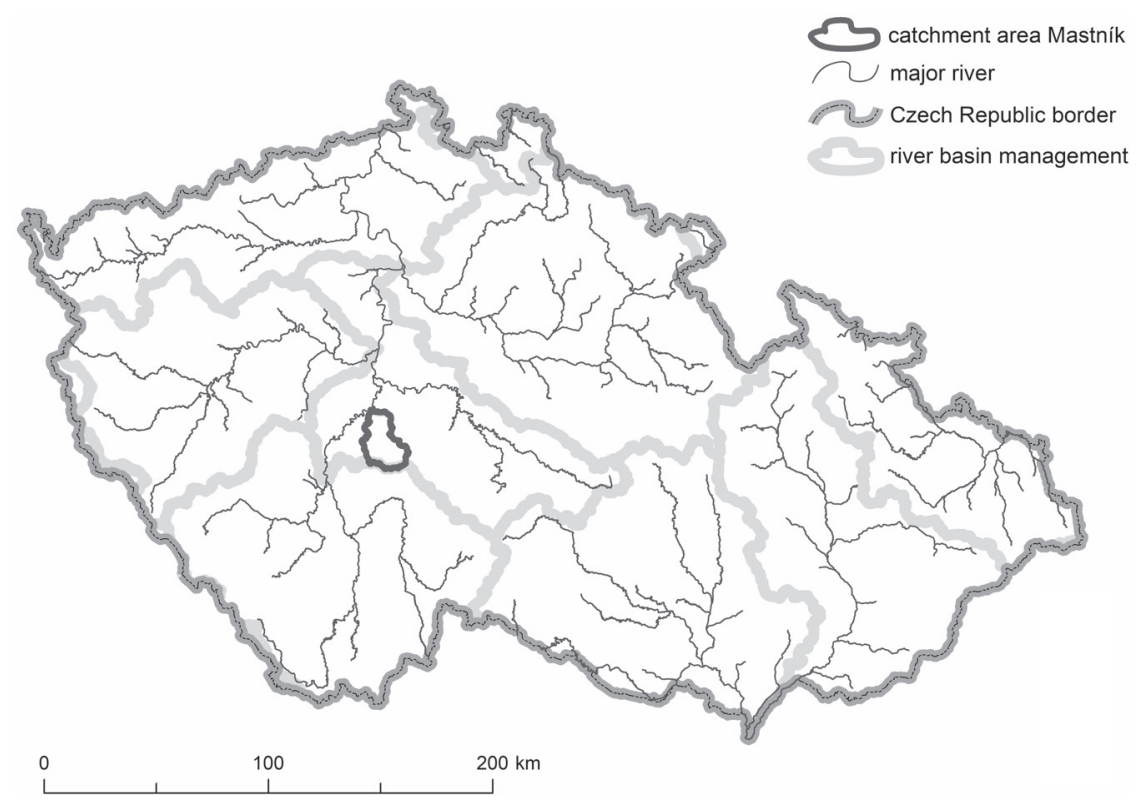

Fig. 1 - Geographical location of the Mastník river basin 
and highlands and from a geomorphological point of view, the area can by divided into two parts. The northern part of the catchment area is occupied by the Benešov Uplands, the Vlašim Uplands protrude into its southern part. The entire catchment area is constituted by granitoids of the Central Bohemian Pluton, with its erosion and denudation relief. The main type of soil cover is cambisol. From a climatic point of view, the catchment belongs, according to Quitt in Landscape Atlas of Czechia (Atlas krajiny ČR 2009), to the warm and moderately warm climatic region. The average air temperature is around $8^{\circ} \mathrm{C}$, with an annual rainfall of about $620 \mathrm{~mm}$.

The overall length of the Mastník stream is $49.5 \mathrm{~km}$ and catchment area is about $331.5 \mathrm{~km}^{2}$. The stream's spring is at $597.6 \mathrm{~m}$ a.s.l., and it runs into the Slapy Reservoir at $272 \mathrm{~m}$ a.s.l. The Mastník stream has many tributaries, the largest one is being the Sedlecký stream. This flows into the Mastník stream in Sedlčany and its catchment area represents approximately $40 \%$ of the Mastník stream catchment area's total surface. In the catchment area, there are many fishponds and fishpond systems, the largest of them being the Velký Sedlečský fishpond. The catchment area itself is fan-shaped. Significant components of the area's characteristics revolve around land cover and land use. These characteristics depend on physiogeographical and socioeconomic conditions and they are very important for water quality assessment. From the Corine Land Cover (2012) database, 73\% of the territory is composed of sites incorporated into the Agricultural Soil Fund. As for detailed characteristics of the catchment area, $49 \%$ is classified, from the site use point of view, as non-irrigated cropland, with a relatively very low forest area share (18\%). This essential disproportion influences both the flow conditions and the pollution of the watercourses. Erosion of the soil in the river basin is also high. According to the Land Parcel Indentification System (LPIS 2013), more than $58 \%$ of the catchment area is threatened.

\subsection{Flow regime}

Currently, regular monitoring of water levels is being carried out in the Mastník stream catchment area only at the Radíc profile. This profile is situated at the $8.5^{\text {th }}$ river kilometre, and it comprises approximately $81 \%$ of the Mastník stream catchment area's surface. For general assessment of the Mastník stream's flow regime, this is considered to be a closing profile. The Czech Hydrometeorological Institute (CHMI) provided us with data from 1984-2014, for this period, the long-term average discharge is $1,279 \mathrm{~m}^{3} \cdot \mathrm{s}^{-1}$. Long-term development of annual means of discharge on Figure 2. The discharge height amounts to $145.5 \mathrm{~mm}$ and in comparing these data with the average rainfall, we assume that $24 \%$ of the annual precipitation flow away from the catchment area due to surface runoff. The highest average discharge used to be reached in March, with the long-term average discharge in 


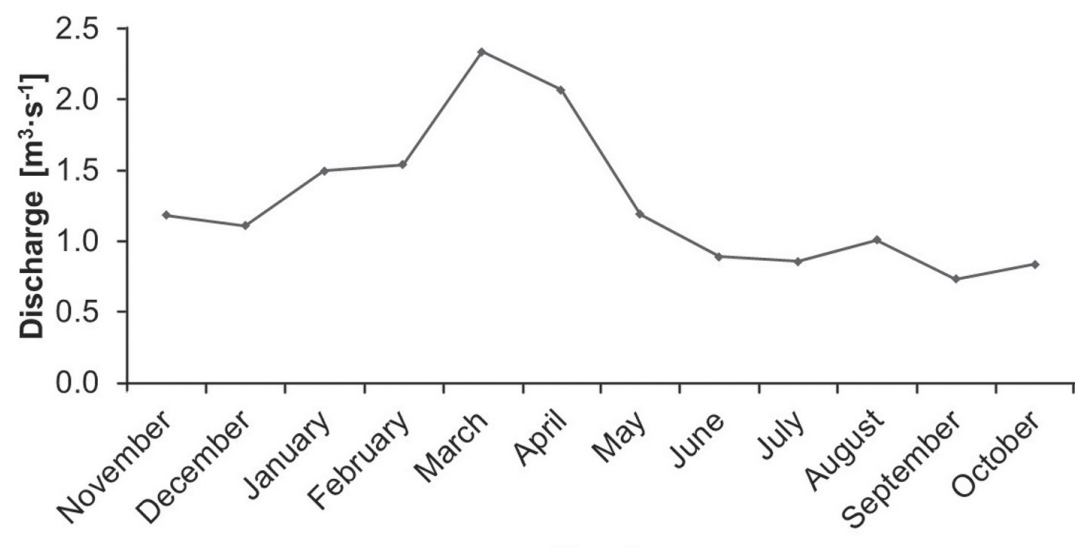

Month

Fig. 2 - Long-term development of annual means of discharge (1984-2014). Data source: CHMI.

this month amounting to $2.34 \mathrm{~m}^{3} \cdot \mathrm{s}^{-1}$. The smallest quantity of water flows through the profile in September $\left(0.73 \mathrm{~m}^{3} \cdot \mathrm{s}^{-1}\right)$. The largest discharge share of the annual amount is in the spring (37\%), the smallest in the autumn (18\%).

\section{Economic activities potentially influencing the water quality}

The settlement structure and economic characteristics in the catchment area focus particularly on the potential source of water pollution in the surface waters. The potential pollution sources can be divided into three groups - agriculture, industry and population.

The catchment area has a predominantly agricultural character, and more than two-thirds of its territory is used for agricultural activities. In the last few years, a loss of cropland is evident in higher situated areas where it has been transformed into pastures and meadows. Animal production is distributed rather unevenly, and backyard livestock farming prevails. Noteworthy from this point of view is the poultry house, DRUHAZ Sedlčany. Greater potential pollution as a consequence of animal production is supposed to exist in higher situated areas and on sites with high gradients and less cropland. In the catchment area, according to the Vltava River Basin Authority (SOE) database, 43 ponds with a total area of $1.882 \mathrm{~km}^{2}$ are also located. These ponds are mainly used for fish farming. Associated artificial feeding also contributes to the pollution of the watercourses. As for plant production, cereal grain and potato growing areas are primarily found in the catchment area. Water pollution from non-point sources is often related to plant production. It concerns mainly fertilisers (nutrients) and pesticides. 
In the catchment area, industrial production is relatively small. Industry is concentrated in Sedlčany, the largest site in the area, as well as in the nearby municipalities. The largest producer of wastewater is the Lobkowicz brewery situated in Vysoký Chlumec town. The brewery produces up to $394 \mathrm{~m}^{3}$ of wastewater daily, but due to its own wastewater treatment facility, it disposes of this itself. The second largest industrial producer is Povltavské dairy in Sedlčany, which produces approximately $150 \mathrm{~m}^{3}$ wastewater daily. In this plant, a wastewater pretreatment facility use flotation technology together with phosphate coagulation. In this way, pretreated wastewater goes into the municipal wastewater treatment facility Sedlčany. Another significant wastewater producer is KDS Sedlčany, which is engaged in the production of cutlery goods. The population is the other significant pollution source, via communal wastewater. Approximately 17,000 people live in the entire catchment area, equating to a very low population density (51 inhabitants per $\mathrm{km}^{2}$ ), with respect to the size of the catchment ares. The population distribution in the catchment area is shown in Figure 3. Here the distribution of the population is expressed in the form of a network of $1 \times 1 \mathrm{~km}$. The figure shows the prevalence of squares with a population of up to 80 per $\mathrm{km}^{2}$. More than 1,000 inhabitants per $\mathrm{km}^{2}$ exist only in two squares in the town of Sedlčany (darkest colour; ČSÚ 2011). Across the entire catchment area, only three municipalities contain more than 1,000 inhabitants - Sedlčany, Sedlec-Prčice and Kosova Hora. These sites have new or renovated wastewater management facilities. Apart from these sites, other municipalities have their own wastewater treatment plants (WWTPs): Jesenice, Heřmaničky, Křečovice and Vojkov. For several years, a WWTP

Table 1 - Waste water treatment plants, quantity discharge of selected parameters into surface water, and number of connected inhabitants.

\begin{tabular}{|c|c|c|c|c|c|c|}
\hline ID & Waste water treatment & $\begin{array}{c}\mathrm{BOD}_{5} \\
{\left[\mathrm{~kg} \cdot \text { year }^{-1}\right]}\end{array}$ & $\begin{array}{c}\text { COD } \\
{\left[\mathrm{kg} \cdot \text { year }^{-1}\right]}\end{array}$ & $\begin{array}{c}\mathrm{N}-\mathrm{NHH}_{4}^{+} \\
{\left[\mathrm{kg} \cdot \text { year }^{-1}\right]}\end{array}$ & $\begin{array}{c}\text { TP } \\
{\left[\mathrm{kg} \cdot \text { year }^{-1}\right]}\end{array}$ & $\begin{array}{l}\text { Number of } \\
\text { connected } \\
\text { inhabitants }\end{array}$ \\
\hline 1 & 1. SčV Př́bram Heřmaničky ČoV & 174.13 & $1,558.06$ & 26.23 & 60.95 & 468 \\
\hline 2 & 1. SčV Př́bram Jesenice ČOV & 95.59 & 721.04 & 102.84 & 75.48 & 409 \\
\hline 3 & 1. SčV Příbram Kosova Hora ČOV & 409.30 & $3,621.64$ & 73.77 & 116.94 & 816 \\
\hline 4 & 1. SčV Př́bram Křečovice ČoV & 12.10 & 156.52 & 1.82 & 30.34 & 250 \\
\hline 5 & Obec Př́íčovy Čov & 51.82 & 646.49 & 54.17 & 0.00 & 296 \\
\hline 6 & 1. SčV Př́bram Sedlčany ČOV & $2,035.10$ & $17,413.20$ & 824.91 & 855.18 & 5,000 \\
\hline 7 & Služby Sedlec-Prčice ČOV & 342.48 & $3,614.08$ & 51.63 & 320.10 & 1,493 \\
\hline 8 & 1. SčV Příbram SkiRelax Monínec ČOV & 30.32 & 317.46 & 2.94 & 24.64 & \\
\hline 9 & Obec Vojkov ČOV & 453.02 & $1,418.06$ & 141.20 & 52.79 & 300 \\
\hline 10 & Městys Vysoký Chlumec Čov & 72.65 & 557.55 & 15.25 & 29.48 & 500 \\
\hline \multirow[t]{2}{*}{11} & Pivovar Vysoký Chlumec ČOV & 456.13 & $3,568.26$ & 45.84 & 81.37 & \\
\hline & Total & $4,132.64$ & $33,592.37$ & $1,340.59$ & $1,647.28$ & 9,532 \\
\hline
\end{tabular}




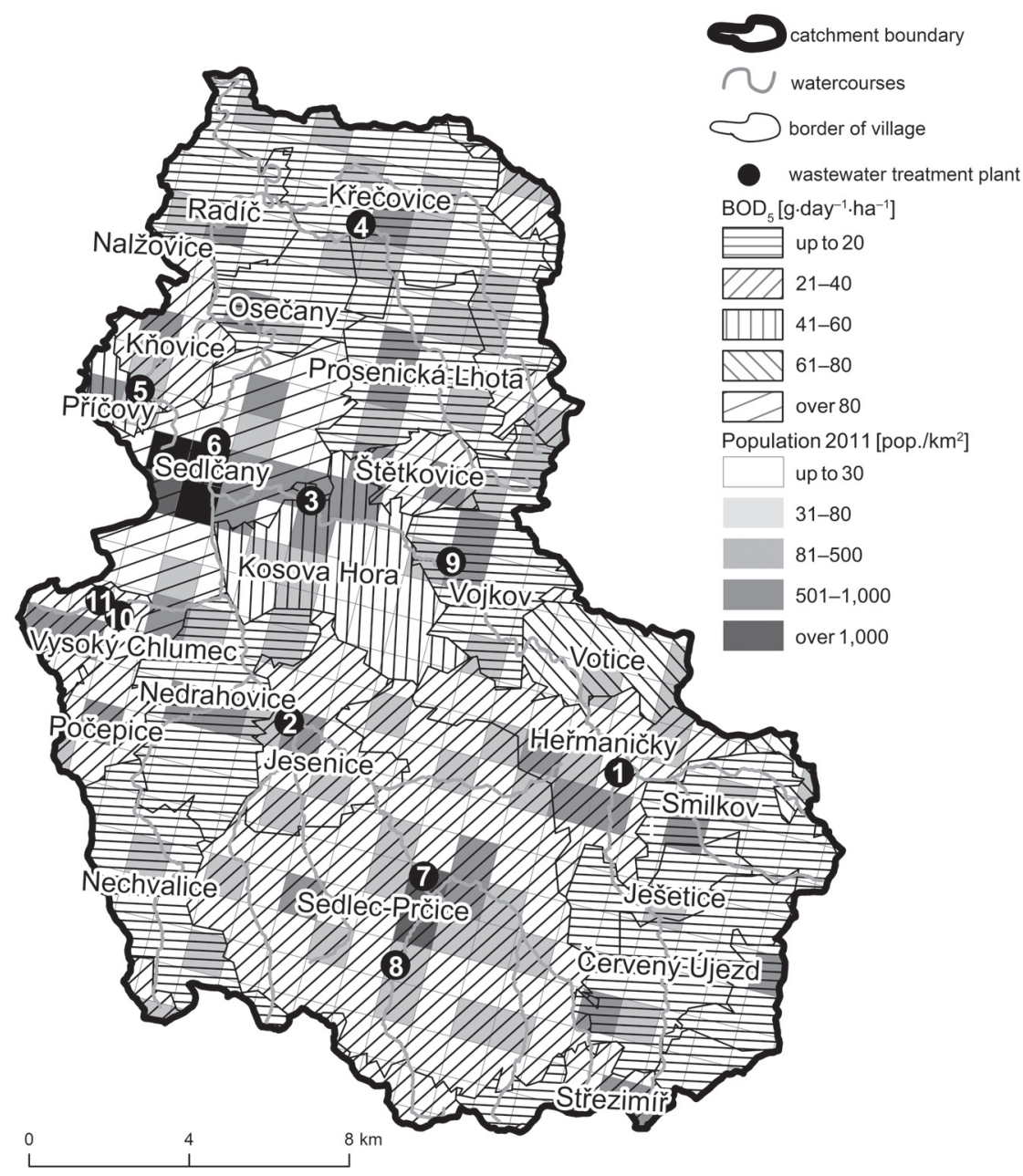

Fig. 3 - Cartogram of potential load by population - $\mathrm{BOD}_{5}$ indicator, population density (2011) and location of WWTPs in catchment

has been functioning in Př́čovy, and the construction of a similar plant has been completed in Vysoký Chlumec. All of the aforementioned WWTPs are a secondary purification step. Table 1 shows the number of selected discharged substances and the number of connected inhabitants for each WWTP. Figure 3 also shows their location using the ID of the WWTP from Table 1. According to data from the Water Information System (2017), 9,532 inhabitants are connected to WWTPs in the catchment area. This is about $56 \%$ of the total population in the catchment area. For comparison with the entire Central Bohemian region, $71.6 \%$ of the population is connected to WWTPs (CZSO 2011). 
For the catchment area, potential pollution by the population permanently living in the area has been calculated in which the impact of the above mentioned WWTP has not been included. One inhabitant produces approximately $60 \mathrm{~g}$ of five-day biochemical oxygen demand $\left(\mathrm{BOD}_{5}\right)$ per day (Pitter 2009). With this kind of pollution, no system of wastewater treatment has been projected. From Figure 3, it is obvious that the largest potential pollution exists in Sedlčany. In this city, potential pollution reaches $125 \mathrm{BOD}_{5} \cdot g \cdot \mathrm{day}^{-1} \cdot \mathrm{ha}^{-1}$. Potential pollution exceeding $40 \mathrm{BOD}_{5} \cdot g \cdot \mathrm{day}^{-1} \cdot \mathrm{ha}^{-1}$ is achieved in the villages of Pŕíčovy, Kosova Hora and Votice, but only small part of the area of this town falls into the river basin and the WWTP is outside the Mastník catchment. The other municipalities do not achieve such high potential pollution levels. When comparing the location of the WWTP and the concentration of the population, it is obvious that, in most municipalities with a higher pollution potential, the WWTP has already been built. Unfortunately, this potential assessment affects the size of the area of each village. As shown in Figure 3, there are still several municipalities with a higher population (grey squares), where a WWTP will need to be built; for example, Prosenická Lhota, Nedrahovice, Radíč and Ješetice.

\section{Methodology of surface water quality analysis}

Surface water quality has been assessed according to data from SOE. We obtained 23 indicators demonstrating water quality (water temperature, $\mathrm{pH}$, electrolytic conductivity, dissolved $\mathrm{O}_{2}, \mathrm{BOD}_{5}$, chemical oxygen demand ( $\mathrm{COD}_{\mathrm{Mn}}$ and $\mathrm{COD}_{\mathrm{cr}}$ ), total organic carbon (TOC), total nitrogen (TN), N-NH${ }_{4}^{+}, \mathrm{N}^{-\mathrm{NO}_{3}^{-}}$, total phosphorus (TP), $\mathrm{Cl}^{-}, \mathrm{SO}_{4}^{2-}, \mathrm{Mn}, \mathrm{Fe}, \mathrm{Ca}, \mathrm{Mg}$, Escherichia coli bacteria, saprobe index of macrozoobenthos (INDBENT), chlorophyll- $\alpha, \mathrm{P}_{-} \mathrm{PO}_{4}^{3-}, \mathrm{N}-\mathrm{NO}_{2}^{-}$and saturation $\mathrm{O}_{2}$. Monitoring results were available from two permanent, and seven additional, profiles from 1995 which have been monitored on a limited scale and in short time series. These data were complemented by six other profiles where we conducted our own waterquality analysis. The profiles were chosen in such a manner that they showed, in the best possible way, the impact of all the factors influencing water quality in the watercourses. The locations of the studied profiles are shown in Figure 4.

This study's sampling was carried out at monthly intervals from April 2012 to June 2013. At all these profiles, 15 probes were taken and the following indicators were assessed: water temperature, $\mathrm{pH}$, electrolytic conductivity, dissolved $\mathrm{O}_{2}$, $\mathrm{BOD}_{5}, \mathrm{COD}_{\mathrm{Mn}}, \mathrm{N}-\mathrm{NH}_{4}^{+}, \mathrm{N}-\mathrm{NO}_{3}^{-}, \mathrm{N}-\mathrm{NO}_{2}^{-}, \mathrm{P}_{-} \mathrm{PO}_{4}^{3-}, \mathrm{Cl}^{-}, \mathrm{Mn}, \mathrm{Fe}, \mathrm{Ca}$, acidity, alkalinity and water hardness. All probes have been complemented by values of immediate discharge that were measured by means of a hydrometric propeller. Sample analyseiswere performed in the Laboratory for Water Protection at the Institute for Environmental Studies of the Faculty of Science of the Charles University. 


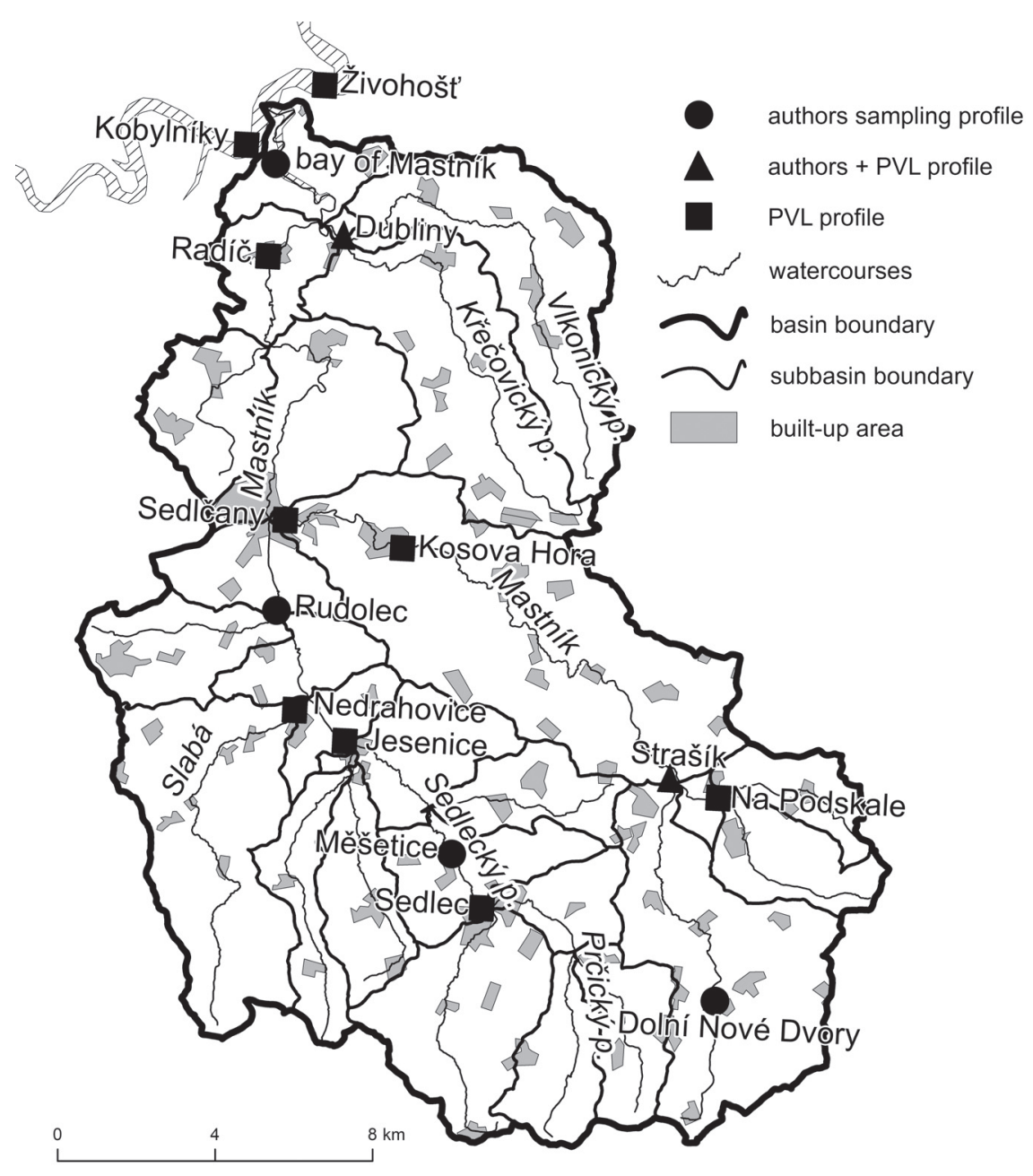

Fig. 4 - Sampling profile positions

The water quality is variable, and rapid changes in space and time occured quite often; for this reason, there were several approaches used to assess the surface water quality. Herein, we have placed emphasis on the assessement according to the ČSN 75 7221. This standard classifies flowing waters according to their quality, using five categories (Table 2). The classification is then applied according to the characteristic value of the concentration (C90). The calculation procedure for this value, which is defined as the value with a no-overrun probability of $90 \%$, is indicated in the technical standard. Based on the value C (90), the individual indicators are classified into water-quality categories according to their limit values. The overall quality of the watercourse or body of water is assessed by means of the worst-case value. 
By analysing the data of the concentrations of selected parameters and discharge on the studied profiles, the predominant source of pollution is derived. The origin of the substance can be derived from changes in concentration depending on the change in flow. Using a correlation coefficient (CC), the parameter is assigned to a point or surface pollution source. If the CC comes out positively, the concentration increases with the flow, which is indicative of a non-point source of pollution. Conversely, a negative value of the CC means decreasing concentration with increasing flow, which means there is a point source. CC values above 0.3 are taken to be significant (Vyskoč et al. 2014). Above 0.7 as very significant.

In the case of longer time-series profiles, the Mann-Kenndall test (MKT) is used to evaluate the trend. Seasonal MKTs were subject to a monthly time-series of concentrations for the Kosova Hora profiles for the period 1995-2016, and for the Radíc profile from 1996-2016. The significance of the trend was tested at a level of 0.05 .

Last, but not least, we used the material ablation balance and specific material ablation data. Information on the chosen indicator concentration was supplemented in this evaluation a fundamental hydrological variable - discharge which interconnects the immission and emission situation in the catchment area (Langhammer 2009). For the emission evaluation, a simple relation for material ablation calculation was used: $L=c \cdot Q$ (where $L$ is the material ablation volume, $c$ is the studied indicator's concentration and $Q$ is the immediate discharge). Another possibility for analysis was provided by the specific material ablation (SMA) assessment. This gives evidence of the intensity distribution of the pollution load in individual parts of the catchment area. This indicator shows the contribution of the individual parts to the total load balance per certain time unit (Janský, Judová 2005; Langhammer, Kliment 2009). In this case, the material ablation depicted the studied substance volume (in $\mathrm{kg}$ ) that flows away from $1 \mathrm{~km}^{2}$ per year. For the catchment area, the SMA was calculated as follows: $S=T \cdot c \cdot Q \cdot P^{-1}$ (where $S$ is the SMA volume, $T$ is time, $c$ is the studied indicator's concentration, $Q$ is the immediate discharge and $P$ is the catchment area surface).

\section{Results}

The results of this work are divided in two groups according to the data sources. To evaluate the water quality, we chose different assessment approaches. The basic way of classification is evaluation according to the Czech Technical Standard (ČSN 757221 ), trend analysis and dependency assessment of flow concentrations. The first part contains the assessed data delivered by the SOE. This evaluation was complemented by the results of proper analysis, including the dependency assessment. Conclusions and discussion were drawn based on all available data. 


\subsection{Evaluation based on data from the water course administrator}

The profile that has been monitored for the longest period of time in the entire catchment area is Kosova Hora, where concentration development can be followed since 1995. Another important profile is Radíč, at which the dependency assessment can be realised relating to discharge. The extent of the studied indicators enabled a complex assessment of water quality according to ČSN 757221 , and because most other profiles do not meet these conditions relating to the total extent of studied indicators, the studied profiles can be classified into water-quality categories only indicatively. In Table 3, average of the assessed values are shown for chosen indicators, as well as the median and the characteristic value C (90) using which the indicator is classified into a water-quality category. The remaining SOE net profiles were monitored only to a limited extent, and over limited periods of time. In this paper, they serve only to illustrate the entire situation.

The Kosova Hora profile belongs to water-quality Category III. This is due to the enhanced concentrations of $\mathrm{TN}, \mathrm{N}^{-\mathrm{NO}_{3}^{-}}$and TP. In this profile, the development of the chosen indicator concentrations has also been studied. The N-NO${ }_{3}^{-}$ concentration depends on the vegetation period. In February, maximum average concentrations reached almost $8 \mathrm{mg} \cdot \mathrm{l}^{-1}$. On the contrary, minimum concentrations in the summer months were $2 \mathrm{mg} \cdot \mathrm{l}^{-1}$. In 1995-1996, the average concentration reached $6.68 \mathrm{mg} \cdot \mathrm{l}^{-1}$, but in the latest studied years, this average concentration dropped to $3.6 \mathrm{mg} \cdot \mathrm{l}^{-1}$. The resulting values show that a decrease in the non-point pollution source's impact on nitrogen concentration in the water occurred over the last decade. This was also confirmed by the analysis of seasonal MKT, the results of which indicate a downward trend in concentrations of all selected water-quality parameters. In the case of nitrogen, a significant trend is only found for $\mathrm{N}^{-\mathrm{NO}_{3}^{-}}$, where the MKT value was $-4,693$. The results of the other parameters can be found in Table 2.

Table 2 - Trend analysis in time series using the MKT

\begin{tabular}{|c|c|c|c|c|c|c|}
\hline \multirow[t]{2}{*}{ Parameter } & \multicolumn{3}{|c|}{ Kosova Hora } & \multicolumn{3}{|c|}{ Radič } \\
\hline & $z$ value & $p$ value & trend & $z$ value & $p$ value & trend \\
\hline $\mathrm{BOD}_{5}$ & -2.477 & 0.013 & $\downarrow$ & -4.314 & 0.000 & $\downarrow$ \\
\hline TN & -0.788 & 0.431 & & -1.275 & 0.202 & \\
\hline $\mathrm{N}-\mathrm{NH}_{4}^{+}$ & -1.429 & 0.153 & & -7.003 & 0.000 & $\downarrow$ \\
\hline $\mathrm{N}-\mathrm{NO}_{3}^{-}$ & -4.693 & 0.000 & $\downarrow$ & -6.039 & 0.000 & $\downarrow$ \\
\hline $\mathrm{N}-\mathrm{NO}_{2}^{-}$ & -1.225 & 0.221 & & -6.529 & 0.000 & $\downarrow$ \\
\hline TP & -3.823 & 0.000 & $\downarrow$ & -7.533 & 0.000 & $\downarrow$ \\
\hline chlorophyll- $\alpha$ & \multicolumn{3}{|c|}{ discontinuous data } & 1.588 & 0.112 & \\
\hline
\end{tabular}

Note: $z$ value - Mann-Kendall statistic, $p$ value - level of significance 
Table 3 - Water quality of state sampling profiles assessed according to ČSN 757221 (2015-2016)

\begin{tabular}{|c|c|c|c|c|c|c|c|c|}
\hline \multirow{2}{*}{$\frac{\text { Name of profile }}{\text { Index }}$} & \multicolumn{4}{|c|}{ Radič } & \multicolumn{4}{|c|}{ Kosova Hora } \\
\hline & Mean & Median & $C(90)$ & Class & Mean & Median & $C(90)$ & Class \\
\hline Water temperature $\left[{ }^{\circ} \mathrm{C}\right]$ & 11.21 & 11.45 & & & 10.45 & 10.55 & & \\
\hline $\mathrm{pH}$ & 7.92 & 7.90 & & & 7.75 & 7.70 & & \\
\hline Conductivity $\left[\mathrm{mS} \cdot \mathrm{m}^{-1}\right]$ & 48.38 & 45.40 & 60.76 & II & 31.43 & 31.00 & 32.80 & I \\
\hline insoluble matter at $105^{\circ} \mathrm{C}\left[\mathrm{mg} \cdot l^{-1}\right]$ & 10.82 & 9.40 & 18.49 & II & 11.25 & 6.80 & 24.57 & ॥ \\
\hline Dissolved oxygen $\left[\mathrm{mg} \cdot \mathrm{l}^{-1}\right]$ & 11.20 & 11.35 & 7.79 & ॥ & 11.18 & 10.75 & 7.97 & ॥ \\
\hline Saturation $\mathrm{O}_{2}[\%]$ & 102.17 & 99.00 & & & 101.54 & 99.50 & & \\
\hline $\mathrm{BOD}_{5}\left[\mathrm{mg} \cdot \mathrm{l}^{-1}\right]$ & 2.71 & 2.80 & 4.12 & II & 1.82 & 1.45 & 3.07 & ॥ \\
\hline $\mathrm{COD}_{\mathrm{cr}}\left[\mathrm{mg} \cdot \mathrm{l}^{-1}\right]$ & 20.63 & 20.50 & 24.72 & ॥ & 16.54 & 16.00 & 21.12 & ॥ \\
\hline $\mathrm{COD}_{\text {Mn }}\left[\mathrm{mg} \cdot \mathrm{l}^{-1}\right]$ & & & & & 0.11 & 0.09 & 0.19 & ॥ \\
\hline $\mathrm{TOC}\left[\mathrm{mg} \cdot \mathrm{l}^{-1}\right]$ & 9.16 & 9.35 & 10.98 & III & 7.23 & 7.20 & 10.57 & III \\
\hline $\mathrm{TN}\left[\mathrm{mg} \cdot \mathrm{l}^{-1}\right]$ & 4.28 & 3.70 & 6.86 & III & 4.38 & 3.75 & 7.86 & III \\
\hline $\mathrm{N}-\mathrm{NH}_{4}^{+}\left[\mathrm{mg} \cdot \mathrm{l}^{-1}\right]$ & 0.10 & 0.08 & 0.20 & $\|$ & 0.05 & 0.04 & 0.08 & I \\
\hline $\mathrm{N}-\mathrm{NO}_{3}^{-}\left[\mathrm{mg} \cdot \mathrm{l}^{-1}\right]$ & 3.50 & 3.05 & 5.74 & III & 3.61 & 2.70 & 6.66 & III \\
\hline $\mathrm{N}-\mathrm{NO}_{2}^{-}\left[\mathrm{mg} \cdot \mathrm{l}^{-1}\right]$ & 0.04 & 0.03 & 0.07 & $\|$ & 0.02 & 0.01 & 0.03 & I \\
\hline $\mathrm{TP}\left[\mathrm{mg} \cdot \mathrm{l}^{-1}\right]$ & 0.24 & 0.18 & 0.45 & IV & 0.13 & 0.09 & 0.23 & III \\
\hline $\mathrm{P}-\mathrm{PO}_{4}^{3-}\left[\mathrm{mg} \cdot \mathrm{l}^{-1}\right]$ & 0.16 & 0.10 & & & 0.07 & 0.04 & & \\
\hline $\mathrm{Ca}\left[\mathrm{mg} \cdot \mathrm{l}^{-1}\right]$ & 43.50 & 43.50 & 53.00 & & 32.00 & 32.00 & & \\
\hline $\mathrm{Mg}\left[\mathrm{mg} \cdot \mathrm{l}^{-1}\right]$ & 13.67 & 13.50 & 16.00 & & 10.36 & 10.00 & & \\
\hline Coli bacteria $\left[\mathrm{KTJ} \cdot \mathrm{ml}^{-1}\right]$ & 9.68 & 3.95 & 37.54 & ॥ & 5.09 & 2.25 & 12.50 & । \\
\hline chlorophyll- $\alpha\left[\mu \mathrm{g} \cdot \mathrm{l}^{-1}\right]$ & 28.98 & 20.50 & 55.00 & IV & 11.15 & 9.80 & 18.00 & ॥ \\
\hline $\mathrm{Fe}\left[\mathrm{mg} \cdot \mathrm{l}^{-1}\right]$ & & & & & 0.43 & 0.29 & 0.84 & $\|$ \\
\hline $\mathrm{Mn}\left[\mathrm{mg} \cdot \mathrm{l}^{-1}\right]$ & & & & & 5.37 & 5.25 & 6.95 & $\|$ \\
\hline Overall water quality class & & & & IV & & & & III \\
\hline
\end{tabular}

Data source: SOE

Also of interest is information about phosphorus, the second most important nutrient. TP reached a maximum concentration in June (the long-term average value is $0.13 \mathrm{mg} \cdot \mathrm{l}^{-1}$ ) and minimum values were measured during the winter and spring months. Figure 5 suggests a decreasing indicator trend. This trend was also confirmed by the MKT result (see Table 2). However, since 2010, there has been a moderate increase in concentrations. Especially in the summer months at lower flows, which reflects the greater influence of point sources of pollution. The same trend applies to the $\mathrm{P}_{-} \mathrm{PO}_{4}^{3-}$ indicator. The concentration development showed a balanced course for both indicators. In this part of the catchment area, there were no changes in phosphorus supply, based on TP concentration; however, despite this positive downward trend in phosphorus concentrations, no significant changes in phosphorus supply was observed into the surface water, and for that reason, this profile was classified as water quality Category III for the entire studied period. 


\begin{tabular}{|c|c|c|c|c|c|c|c|c|}
\hline \multirow{2}{*}{$\begin{array}{l}\text { Name of profile } \\
\text { Index }\end{array}$} & \multicolumn{4}{|c|}{ Dubliny } & \multicolumn{4}{|c|}{ Jesenice } \\
\hline & Mean & Median & $C(90)$ & Class & Mean & Median & $C(90)$ & Class \\
\hline Water temperature $\left[{ }^{\circ} \mathrm{C}\right]$ & 10.30 & 10.90 & & & 10.88 & 11.10 & & \\
\hline $\mathrm{pH}$ & 7.81 & 7.80 & & & 7.59 & 7.60 & & \\
\hline Conductivity $\left[\mathrm{mS} \cdot \mathrm{m}^{-1}\right]$ & 42.92 & 42.40 & 50.29 & $\|$ & 40.19 & 40.35 & 45.76 & $\|$ \\
\hline insoluble matter at $105^{\circ} \mathrm{C}\left[\mathrm{mg} \cdot \mathrm{l}^{-1}\right]$ & 13.95 & 8.10 & 35.00 & III & 15.11 & 9.00 & 34.86 & III \\
\hline Dissolved oxygen $\left[\mathrm{mg} \cdot \mathrm{l}^{-1}\right]$ & 11.42 & 11.10 & 8.44 & II & 10.71 & 10.00 & 7.45 & III \\
\hline Saturation $0_{2}[\%]$ & 103.03 & 100.40 & & & 97.90 & 95.50 & & \\
\hline $\mathrm{BOD}_{5}\left[\mathrm{mg} \cdot l^{-1}\right]$ & 2.43 & 1.80 & 4.73 & III & 2.63 & 2.45 & 3.97 & $\|$ \\
\hline $\mathrm{COD}_{\mathrm{cr}}\left[\mathrm{mg} \cdot \mathrm{l}^{-1}\right]$ & 21.39 & 18.50 & 33.33 & III & 22.46 & 21.00 & 28.92 & III \\
\hline \multicolumn{9}{|l|}{$\mathrm{COD}_{\mathrm{Mn}}\left[\mathrm{mg} \cdot \mathrm{l}^{-1}\right]$} \\
\hline $\mathrm{TOC}\left[\mathrm{mg} \cdot \mathrm{l}^{-1}\right]$ & 9.43 & 8.65 & 14.02 & III & 9.53 & 9.50 & 12.16 & III \\
\hline $\mathrm{TN}\left[\mathrm{mg} \cdot \mathrm{l}^{-1}\right]$ & 5.94 & 5.70 & 8.75 & III & 4.07 & 3.70 & 6.34 & III \\
\hline $\mathrm{N}-\mathrm{NH}_{4}^{+}\left[\mathrm{mg} \cdot \mathrm{l}^{-1}\right]$ & 0.06 & 0.03 & 0.11 & 1 & 0.09 & 0.08 & 0.16 & 1 \\
\hline $\mathrm{N}-\mathrm{NO}_{3}^{-}\left[\mathrm{mg} \cdot \mathrm{l}^{-1}\right]$ & 4.75 & 4.60 & 7.32 & III & 3.22 & 3.05 & 5.25 & III \\
\hline $\mathrm{N}-\mathrm{NO}_{2}^{-}\left[\mathrm{mg} \cdot \mathrm{l}^{-1}\right]$ & 0.02 & 0.02 & 0.04 & 1 & 0.03 & 0.03 & 0.06 & $\|$ \\
\hline $\mathrm{TP}\left[\mathrm{mg} \cdot \mathrm{l}^{-1}\right]$ & 0.14 & 0.13 & 0.23 & III & 0.26 & 0.23 & 0.46 & IV \\
\hline $\mathrm{P}-\mathrm{PO}_{4}^{3-}\left[\mathrm{mg} \cdot \mathrm{l}^{-1}\right]$ & 0.07 & 0.05 & & & 0.16 & 0.12 & & \\
\hline $\mathrm{Ca}\left[\mathrm{mg} \cdot \mathrm{l}^{-1}\right]$ & 48.50 & 44.50 & 61.00 & & 40.33 & 39.50 & 50.00 & \\
\hline$M g\left[\mathrm{mg} \cdot l^{-1}\right]$ & 14.33 & 14.00 & 16.00 & & 12.92 & 13.00 & 14.00 & \\
\hline Coli bacteria $\left[\mathrm{KT} J \cdot \mathrm{ml}^{-1}\right]$ & 8.35 & 3.25 & 29.63 & ॥ & 18.74 & 11.30 & 49.18 & ॥ \\
\hline chlorophyll- $\alpha\left[\mu \mathrm{g} \cdot \mathrm{l}^{-1}\right]$ & 6.56 & 4.4 & 12.00 & $\|$ & 13.24 & 15.00 & 19.00 & $\|$ \\
\hline \multicolumn{9}{|l|}{$\mathrm{Fe}\left[\mathrm{mg} \cdot \mathrm{l}^{-1}\right]$} \\
\hline \multicolumn{9}{|l|}{$\mathrm{Mn}\left[\mathrm{mg} \cdot \mathrm{l}^{-1}\right]$} \\
\hline Overall water quality class & & & & III & & & & IV \\
\hline
\end{tabular}

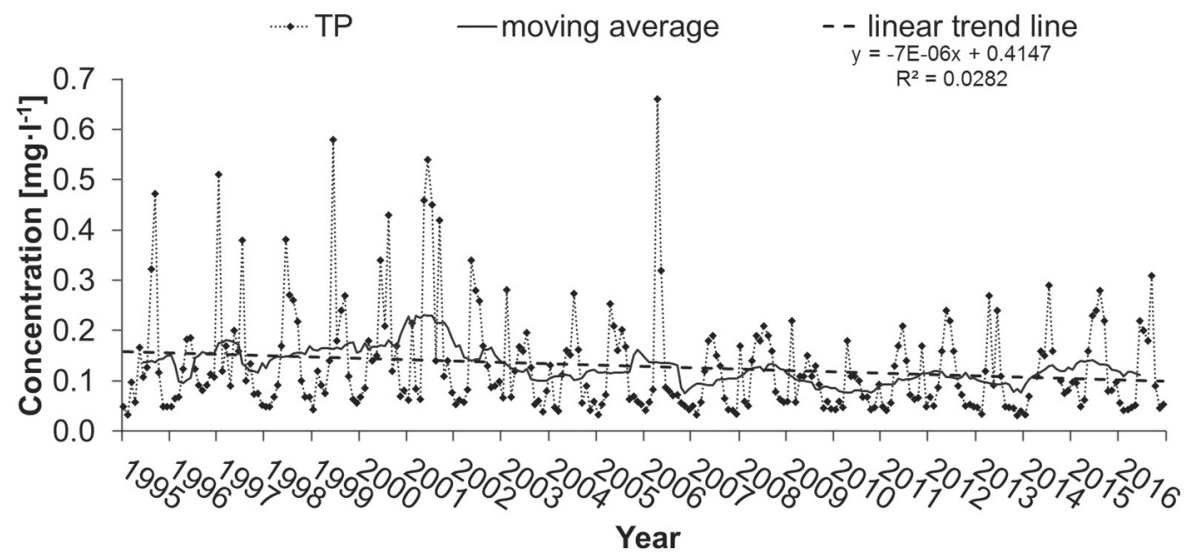

Fig. 5 - Dependence of TP concentrations at the Kosova Hora profile from 1995 to 2016 


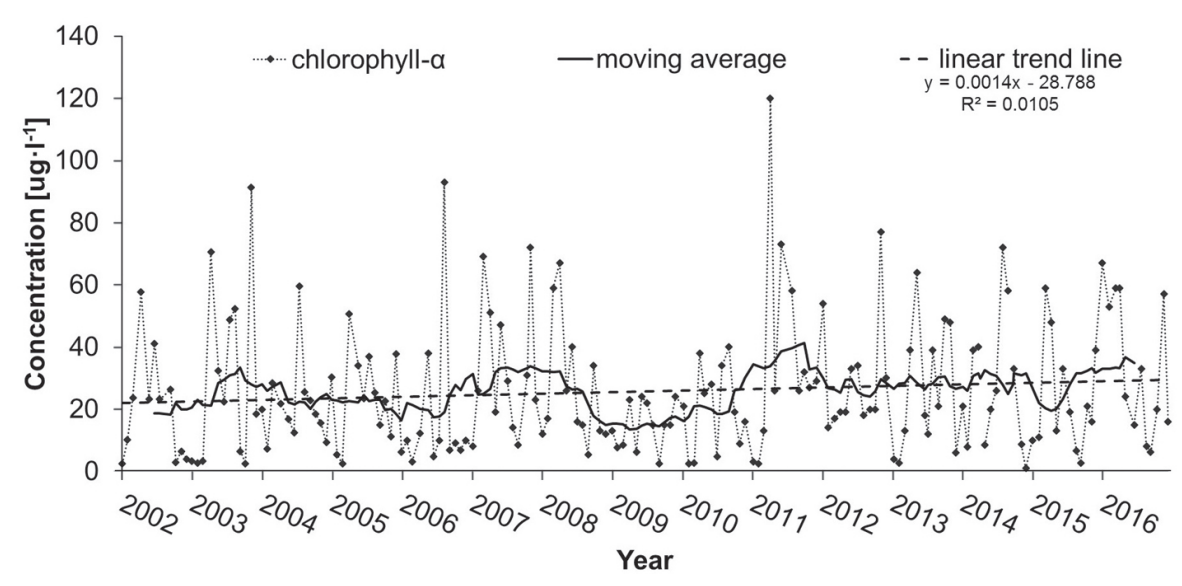

Fig. 6 - Dependence of chlorophyll- $\alpha$ concentrations at the Radíč profile in 2002-2016

The last profile on the Mastník stream watercourse before the Slapy Reservoir water surface surge is Radíč. This is considered to be the catchment area's closing profile, and it represents pollution concentration from the entire catchment area (about $81 \%$ of the catchment area), except for the closing profile Křečovický stream, which is represented by the Dubliny profile. The Dubliny profile is classified into water-quality Category III (Table 3). On the other hand, the Radíc profile has been classified on the basis of high chlorophyll- $\alpha$ concentrations and TP into water-quality Category IV. A slight increase in chlorophyll- $\alpha$ concentrations is shown in Figure 6, which is a graph of the development of concentrations during the monitored period. The linear trendline slightly rises. This is also confirmed by the MKT result, but the result cannot be considered to be significant (Table 2). A significant upward trend was only confirmed for October, however, the positive in this profile is the observed downward trend for 1996-2016 for most selected parameters. In addition to TN, this trend is significant for other parameters. The precise MKT values are in Table 2 . In the case of $\mathrm{N}_{-} \mathrm{NO}_{3}^{-}$, the most dramatic trend is the decrease in spring and summer. The TP indicator shows a significant downward trend throughout the year. This shows a predominant point source phosphorus pollution, and the effectiveness of measures (building and reconstruction of WWTPs) in the catchment. In the Radíc profile, however, the point source of the phosphorus is not significant (Table 4), which is caused by the greater distance from the larger point source, which is the Sedlčany WWTP.

In the Radíc profile, the predominant type of pollution cannot be determined based on the available data. For selected parameters, a CC was used based on concentrations and flow. Table 4 shows the predominance of the point sources of pollution, but these values cannot be viewed as significant. Only in the case of the $\mathrm{N}-\mathrm{NO}_{3}^{-}$is the prevalence of the non-point source of pollution significant (value is 
Table 4 - Significance of concentration and flow dependence - results of the Radíc profile

\begin{tabular}{lcll}
\hline Parameter & Correlation coefficient & Source of poluttion & Significance \\
\hline $\mathrm{BOD}_{5}$ & -0.02 & point & insignificant \\
$\mathrm{COD}$ cr & 0.06 & non-point & insignificant \\
$\mathrm{TOC}$ & -0.03 & point & insignificant \\
$\mathrm{N}-\mathrm{NH}_{4}^{+}$ & -0.06 & point & insignificant \\
$\mathrm{N}-\mathrm{NO}_{3}^{-}$ & 0.34 & non-point & significant \\
$\mathrm{N}-\mathrm{NO}_{2}^{-}$ & -0.10 & point & insignificant \\
$\mathrm{P}-\mathrm{PO}_{4}^{--}$ & -0.23 & point & insignificant \\
$\mathrm{TP}$ & -0.19 & point & insignificant \\
chlorophyll- $\alpha$ & -0.12 & point & insignificant \\
\hline
\end{tabular}

0.34). The highest concentrations were observed particularly during the higher flows in the first months of the year. A dependency on the vegetative season is obvious in the $\mathrm{N}^{-\mathrm{NO}_{3}^{-}}$concentration development. Due to the non-point pollution source, concentrations are higher during the non-vegetation period; during snow melting and higher discharge, the February maximum of $7.5 \mathrm{mg} \cdot \mathrm{l}^{-1}$ reflects greater erosion of material from the fields. In contrast, the minimum was in July $\left(2.7 \mathrm{mg} \cdot \mathrm{l}^{-1}\right)$; when the fields are sown and there is not such a significant material ablation.

According to the complex indicators $\mathrm{BOD}_{5}, \mathrm{COD}_{\mathrm{cr}}$ and TOC, the Radíc profile belongs in water-quality Category II and III Their annual course is relatively

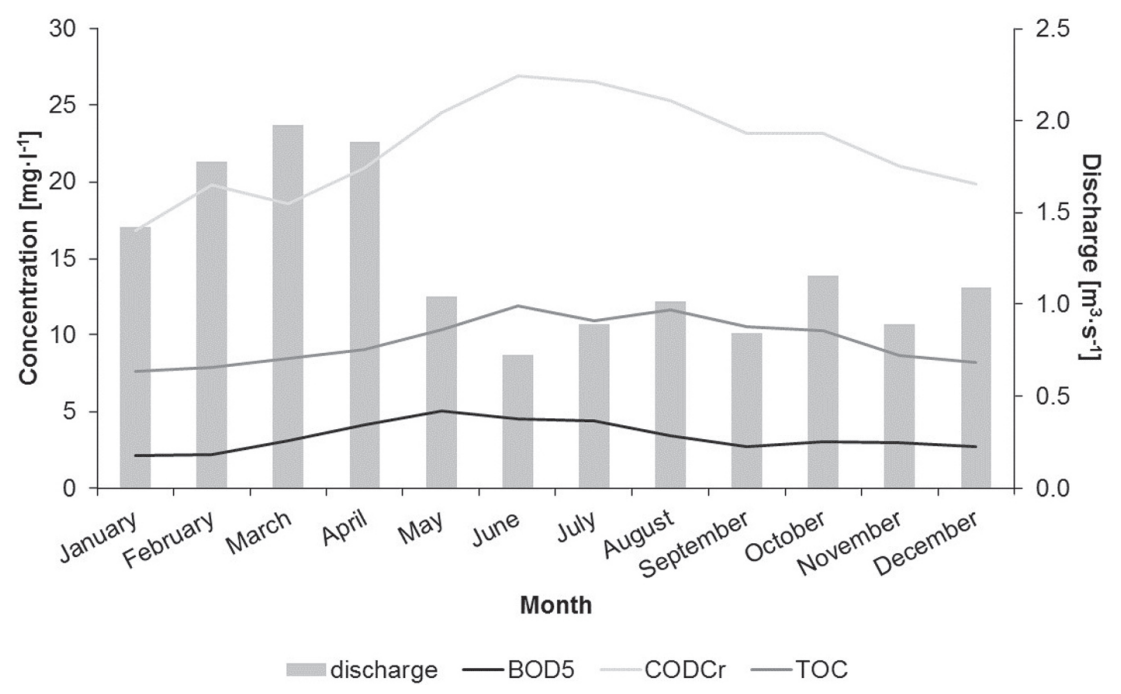

Fig. 7 - Long-term development of $\mathrm{BOD}_{5}, \mathrm{COD}_{\mathrm{cr}}$ and TOC concentrations in the Radíc profile (mean monthly values 1996-2016). Data sources: CHMI, SOE. 


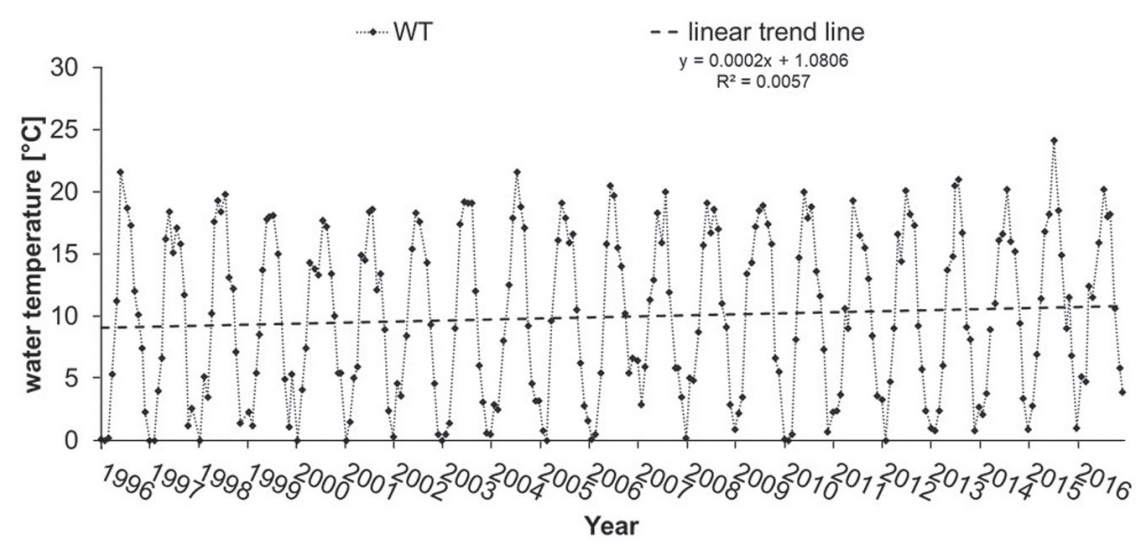

Fig. 8 - Dependence of water temperature (WT) at the Radíč profile in 1996-2016. Data sources: CHMI.

balanced. This is caused by permanent supply of organic substances to the communal and industrial wastewaters. The long-term development of these indicators is shown in Figure 7. The chart shows the monthly average concentrations and is compared with the average monthly flows over the reference period. There was an increase in average surface water temperature, from $9.9^{\circ} \mathrm{C}$ in $1997-1998$ to $11.2^{\circ} \mathrm{C}$ at end of the monitored period in the Radíc profile (Fig. 8).

\subsection{Assessment of the monitoring from authors monitoring}

The monitoring performed in this study was realised at six profiles, and the classification of the individual profiles into water-quality categories according to the ČSN 757221 is shown in Table 6. From this table, it is evident how the profiles are ranked in terms of water-quality class. Only the Dolní Nové Dvory (DND) and Strašík profiles were classified into water-quality Category III. The Měšetice profile was incorporated, according to the indicators, into water-quality Category V. The biggest problem in this stream was with dissolved $\mathrm{O}_{2}$. The other three profiles, situated in the lower sections of the studied watercourses, belong in Category IV. In most of these profiles, the biggest problems were related to concentrations of dissolved $\mathrm{O}_{2}, \mathrm{COD}_{\mathrm{Mn}}$ and $\mathrm{N}-\mathrm{NH}_{4}^{+}$.

The sampling was focused primarily on nutrients and thus on nitrogen compounds and phosphates. During the vegetative period, nitrogen is consumed by the vegetation and also flushed less from surrounding areas. For that reason, their concentrations are lower. On the contrary, their maximum values were reached in the autumn and winter. In the profile the higher concentration also evident with the increased discharge. The consequence of this is a higher impact of 
Table 5 - Significance of concentration and flow dependency - results from this study's sampling profiles

\begin{tabular}{|c|c|c|c|c|c|c|c|c|c|c|c|c|c|c|c|}
\hline \multirow[t]{2}{*}{ Parameter } & \multicolumn{3}{|c|}{ DND } & \multicolumn{3}{|c|}{ Strašk } & \multicolumn{3}{|c|}{ Měšetice } & \multicolumn{3}{|c|}{ Rudolec } & \multicolumn{3}{|c|}{ Dubliny } \\
\hline & $\mathrm{CC}$ & SoP & Sig. & $\mathrm{CC}$ & SoP & Sig. & $\mathrm{CC}$ & SoP & Sig. & $C C$ & SoP & Sig. & CC & SoP & Sig. \\
\hline $\mathrm{BOD}_{5}$ & -0.28 & $P$ & & -0.19 & $\mathrm{P}$ & & -0.02 & $\mathrm{P}$ & & -0.32 & $P$ & S & 0.38 & NP & $S$ \\
\hline $\operatorname{COD}_{\mathrm{Mn}}$ & -0.58 & $\mathrm{P}$ & S & -0.28 & $\mathrm{P}$ & & -0.14 & $P$ & & -0.30 & $P$ & $S$ & 0.08 & NP & \\
\hline $\mathrm{N}-\mathrm{NH}_{4}^{+}$ & -0.08 & $\mathrm{P}$ & & 0.32 & $\mathrm{NP}$ & $S$ & -0.19 & $P$ & & -0.23 & $P$ & & -0.12 & $\mathrm{P}$ & \\
\hline $\mathrm{N}-\mathrm{NO}_{3}^{-}$ & 0.44 & NP & S & 0.84 & $\mathrm{NP}$ & VS & 0.65 & NP & S & 0.81 & NP & VS & 0.07 & NP & \\
\hline $\mathrm{N}-\mathrm{NO}_{2}^{-}$ & -0.72 & $P$ & VS & 0.18 & $\mathrm{NP}$ & & -0.71 & $P$ & VS & -0.52 & $P$ & $S$ & 0.30 & NP & $S$ \\
\hline $\mathrm{P}-\mathrm{PO}_{4}^{3-}$ & -0.54 & P & S & -0.35 & P & $\mathrm{S}$ & -0.64 & P & $S$ & -0.72 & P & VS & -0.80 & P & VS \\
\hline
\end{tabular}

Note: CC - correlation coefficient, SoP - Source of pollution, NP - non-point, P - point, Sig. - Significance, S - significant, VS - very significant

non-point sources of substances when the $\mathrm{N}^{-\mathrm{NO}_{3}^{-}}$is washed out of the soil particularly during the winter thaws and spring snow melt. For the $\mathrm{N}-\mathrm{NO}_{3}^{-}$indicator, the predominance of non-point sources of pollution was found in all observed profiles based on the concentrations and measured discharge. In the case of the Strašík and Rudolec profiles, this correlation was highly significant (Table 5). In the case of $\mathrm{N}-\mathrm{NH}_{4}^{+}$, the pollution sources could not be specified. The $\mathrm{N}^{-\mathrm{NO}_{2}^{-}}$parameter differs in each profile, but it has the predominance of point sources of pollution. Figure 9 shows an example of how the $\mathrm{N}^{-\mathrm{NO}_{3}^{-}}$concentration rises with increased discharge. The material ablation of $\mathrm{N}_{-} \mathrm{NO}_{3}^{-}$corresponds with the profile locations at which the particular impact of agricultural activities is awaited. The total material ablation was $1,388.5 \mathrm{~kg} \cdot \mathrm{year}^{-1}\left(\right.$ i.e. $\left.46.2 \mathrm{~kg} \cdot \mathrm{km}^{-2} \cdot \mathrm{year}^{-1}\right)$. In the case of the Strašík profile, this was also a significant non-point source of pollution for the $\mathrm{N}-\mathrm{NH}_{4}^{+}$indicator, which was evident especially from January 2013 (Figure 9), when material ablation was higher than $10 \mathrm{~g} \cdot \mathrm{s}^{-1}$. The annual material ablation

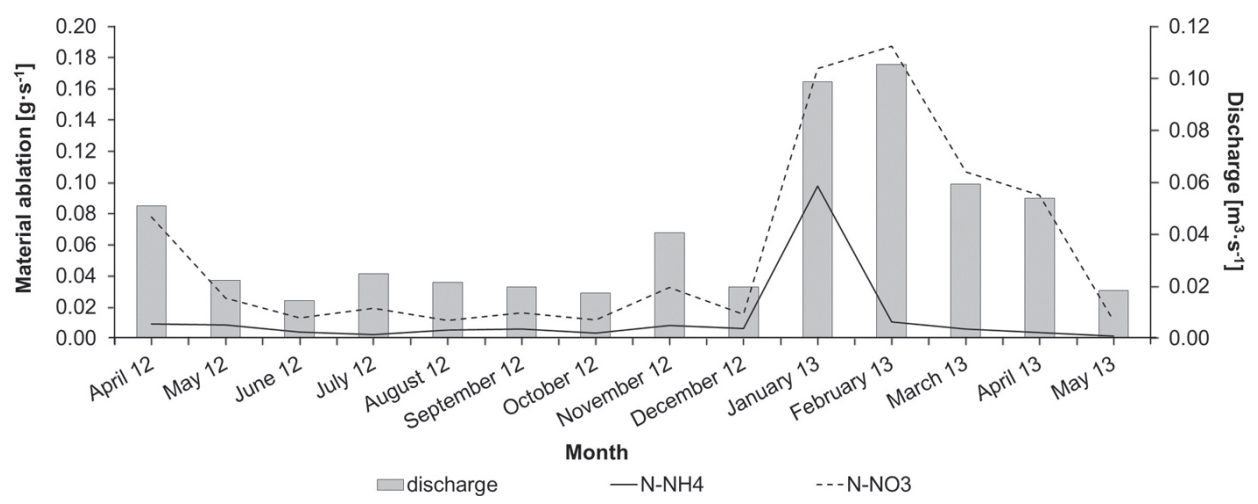

Fig. 9 - Material ablation of $\mathrm{N}-\mathrm{NH}_{4}^{+}, \mathrm{N}-\mathrm{NO}_{3}^{-}$and discharge at the Strašík profile (Mastník stream). 
was $303 \mathrm{~kg}$. The results of material ablation and specific material ablation for selected parameters from this study's monitoring are shown in Table 6.

The phosphorus pollution rate was assessed according to the possibilities of the laboratory only with the help of a $\mathrm{P}^{-\mathrm{PO}_{4}^{3-}}$ indicator. In all the studied profiles, the concentration course depends on discharge. Correlation of the concentration with discharge is highly significant, except for the Strašík profile, where it is only significant (Table 5). From Table 5 it is obvious that the $\mathrm{P}_{-} \mathrm{PO}_{4}^{3-}$ concentration decrease with a rise in watercourse discharge volume. This corresponds to the predominance of the point-pollution sources that assert themselves in a relatively stable way trough the course of the entire year. Maximum concentrations were determined during the summer months, when the smallest discharge was measured. On the other hand, the minimum concentrations depended on snow melt and precipitation during the spring months. The main source of phosphorus is represented primarily by the communal wastewater. Only the profiles influenced by the point-pollution sources - firstly WWTP - had higher concentrations. This was confirmed by the graph of material ablation from the Rudolec profile, as shown in Figure 10. The total $\mathrm{P}_{-} \mathrm{PO}_{4}^{3-}$ material ablation was $1,477 \mathrm{~kg} \cdot \mathrm{year}^{-1}$,

Table 6 - Evaluation of sampling sites according to ČSN 757221 (data from author sampling 2011-2012)

\begin{tabular}{|c|c|c|c|c|c|c|c|c|}
\hline \multirow{2}{*}{$\frac{\text { Name of profile }}{\text { Index }}$} & \multicolumn{4}{|c|}{ Dolní Nové Dvory (DND) } & \multicolumn{4}{|c|}{ Strašík } \\
\hline & Mean & Median & $C(90)$ & WQC & Mean & Median & $C(90)$ & WQC \\
\hline Discharge $\left[\mathrm{m}^{3} \cdot \mathrm{s}^{-1}\right]$ & 0.01 & 0.01 & & & 0.04 & 0.02 & & \\
\hline Water temperature $\left[{ }^{\circ} \mathrm{C}\right]$ & 7.60 & 10.00 & & & 7.93 & 10.00 & & \\
\hline $\mathrm{pH}$ & 7.44 & 7.39 & & & 7.55 & 7.53 & & \\
\hline Conductivity $\left[\mathrm{mS} \cdot \mathrm{m}^{-1}\right]$ & 23.28 & 23.00 & 26.60 & I & 24.55 & 24.60 & 27.70 & I \\
\hline Dissolved oxygen $\left[\mathrm{mg} \cdot \mathrm{l}^{-1}\right]$ & 10.40 & 10.24 & 6.15 & III & 10.61 & 10.76 & 7.11 & III \\
\hline $\mathrm{BOD}_{5}\left[\mathrm{mg} \cdot l^{-1}\right]$ & 2.20 & 1.87 & 4.20 & II & 1.98 & 1.84 & 3.00 & II \\
\hline $\mathrm{COD}_{\mathrm{Mn}}\left[\mathrm{mg} \cdot \mathrm{l}^{-1}\right]$ & 7.51 & 7.76 & 8.50 & II & 7.57 & 7.36 & 9.50 & III \\
\hline $\mathrm{N}-\mathrm{NH}_{4}^{+}\left[\mathrm{mg} \cdot \mathrm{l}^{-1}\right]$ & 0.27 & 0.23 & 0.60 & III & 0.24 & 0.19 & 0.40 & III \\
\hline $\mathrm{N}-\mathrm{NO}_{3}^{-}\left[\mathrm{mg} \cdot \mathrm{l}^{-1}\right]$ & 1.15 & 1.08 & 1.70 & I & 1.10 & 0.90 & 1.80 & I \\
\hline $\mathrm{N}-\mathrm{NO}_{2}^{-}\left[\mathrm{mg} \cdot \mathrm{l}^{-1}\right]$ & 0.03 & 0.02 & 0.05 & II & 0.03 & 0.02 & 0.05 & II \\
\hline $\mathrm{P}-\mathrm{PO}_{4}^{3-}\left[\mathrm{mg} \cdot \mathrm{l}^{-1}\right]$ & 0.06 & 0.04 & 0.12 & & 0.12 & 0.04 & 0.30 & \\
\hline $\mathrm{Cl}^{-}\left[\mathrm{mg} \cdot \mathrm{l}^{-1}\right]$ & 12.77 & 13.27 & 18.25 & I & 14.69 & 14.67 & 21.00 & I \\
\hline $\mathrm{Mn}\left[\mathrm{mg} \cdot \mathrm{l}^{-1}\right]$ & 0.02 & 0.00 & 0.06 & 1 & 0.04 & 0.00 & 0.12 & II \\
\hline $\mathrm{Fe}\left[\mathrm{mg} \cdot \mathrm{l}^{-1}\right]$ & 0.27 & 0.22 & 0.30 & । & 0.22 & 0.21 & 0.35 & I \\
\hline $\mathrm{Ca}\left[\mathrm{mg} \cdot \mathrm{l}^{-1}\right]$ & 38.96 & 37.24 & 51.00 & & 35.53 & 36.44 & 45.00 & \\
\hline Acidity $\left[\mathrm{mmol} \cdot \mathrm{l}^{-1}\right]$ & 0.30 & 0.19 & 0.68 & & 0.32 & 0.27 & 0.58 & \\
\hline Alkalinity $\left[\mathrm{mmol} \cdot \mathrm{l}^{-1}\right]$ & 1.24 & 1.25 & 1.70 & & 1.44 & 1.29 & 1.90 & \\
\hline Overall water quality class (OWQC) & & & & III & & & & III \\
\hline
\end{tabular}


Table 6 (cont.)

\begin{tabular}{|c|c|c|c|c|c|c|c|c|}
\hline \multirow{2}{*}{$\begin{array}{l}\text { Name of profile } \\
\text { Index }\end{array}$} & \multicolumn{4}{|c|}{ Měšetice } & \multicolumn{4}{|c|}{ Rudolec } \\
\hline & Mean & Median & $C(90)$ & WQC & Mean & Median & $C(90)$ & WQC \\
\hline Discharge $\left[\mathrm{m}^{3} \cdot \mathrm{s}^{-1}\right]$ & 0.06 & 0.03 & & & 0.13 & 0.07 & & \\
\hline Water temperature $\left[{ }^{\circ} \mathrm{C}\right]$ & 8.37 & 10.50 & & & 8.13 & 8.00 & & \\
\hline $\mathrm{pH}$ & 7.54 & 7.53 & & & 7.63 & 7.60 & & \\
\hline Conductivity $\left[\mathrm{mS} \cdot \mathrm{m}^{-1}\right]$ & 31.80 & 28.90 & 38.40 & 1 & 32.71 & 31.20 & 39.00 & । \\
\hline Dissolved oxygen $\left[\mathrm{mg} \cdot \mathrm{l}^{-1}\right]$ & 9.05 & 8.88 & 3.85 & v & 9.25 & 9.46 & 5.22 & IV \\
\hline $\mathrm{BOD}_{5}\left[\mathrm{mg} \cdot \mathrm{l}^{-1}\right]$ & 4.28 & 3.65 & 7.00 & III & 3.49 & 3.79 & 5.30 & III \\
\hline $\operatorname{COD}_{M n}\left[\mathrm{mg} \cdot \mathrm{l}^{-1}\right]$ & 10.05 & 9.60 & 13.80 & III & 10.99 & 9.44 & 15.70 & IV \\
\hline $\mathrm{N}-\mathrm{NH}_{4}^{+}\left[\mathrm{mg} \cdot \mathrm{l}^{-1}\right]$ & 0.60 & 0.50 & 1.15 & IV & 0.25 & 0.22 & 0.50 & III \\
\hline $\mathrm{N}-\mathrm{NO}_{3}^{-}\left[\mathrm{mg} \cdot \mathrm{l}^{-1}\right]$ & 0.91 & 0.78 & 1.60 & । & 0.87 & 1.00 & 1.40 & 1 \\
\hline $\mathrm{N}-\mathrm{NO}_{2}^{-}\left[\mathrm{mg} \cdot \mathrm{l}^{-1}\right]$ & 0.06 & 0.05 & 0.10 & II & 0.04 & 0.03 & 0.05 & II \\
\hline $\mathrm{P}-\mathrm{PO}_{4}^{3-}\left[\mathrm{mg} \cdot \mathrm{l}^{-1}\right]$ & 0.35 & 0.23 & 0.80 & & 0.36 & 0.18 & 0.96 & \\
\hline $\mathrm{Cl}^{-}\left[\mathrm{mg} \cdot \mathrm{l}^{-1}\right]$ & 26.88 & 27.38 & 35.00 & 1 & 28.47 & 28.50 & 37.20 & । \\
\hline $\mathrm{Mn}\left[\mathrm{mg} \cdot \mathrm{l}^{-1}\right]$ & 0.14 & 0.12 & 0.24 & II & 0.13 & 0.12 & 0.12 & ॥ \\
\hline $\mathrm{Fe}\left[\mathrm{mg} \cdot \mathrm{l}^{-1}\right]$ & 0.29 & 0.29 & 0.43 & 1 & 0.27 & 0.26 & 0.38 & 1 \\
\hline $\mathrm{Ca}\left[\mathrm{mg} \cdot \mathrm{l}^{-1}\right]$ & 45.85 & 47.15 & 51.00 & & 44.81 & 46.09 & 51.00 & \\
\hline Acidity $\left[\mathrm{mmol} \cdot \mathrm{l}^{-1}\right]$ & 0.37 & 0.29 & 0.77 & & 0.30 & 0.27 & 0.58 & \\
\hline Alkalinity $\left[\mathrm{mmol} \cdot \mathrm{l}^{-1}\right]$ & 2.03 & 2.19 & 2.90 & & 1.97 & 1.87 & 2.70 & \\
\hline Overall water quality class (OWQC) & & & & $\mathrm{V}$ & & & & IV \\
\hline Name of profile & \multicolumn{4}{|c|}{ Dubliny } & \multicolumn{4}{|c|}{ bay of Mastník } \\
\hline Index & Mean & Median & $C(90)$ & WQC & Mean & Median & $C(90)$ & WQC \\
\hline Discharge $\left[\mathrm{m}^{3} \cdot \mathrm{s}^{-1}\right]$ & 0.04 & 0.04 & & & & & & \\
\hline Water temperature $\left[{ }^{\circ} \mathrm{C}\right]$ & 7.20 & 8.00 & & & 10.57 & 12.50 & & \\
\hline $\mathrm{pH}$ & 7.73 & 7.76 & & & 7.92 & 7.77 & & \\
\hline Conductivity $\left[\mathrm{mS} \cdot \mathrm{m}^{-1}\right]$ & 34.59 & 33.30 & 42.00 & ॥ & 25.47 & 25.80 & 32.00 & । \\
\hline Dissolved oxygen $\left[\mathrm{mg} \cdot \mathrm{l}^{-1}\right]$ & 9.86 & 10.05 & 7.41 & III & 10.32 & 11.43 & 5.47 & IV \\
\hline $\mathrm{BOD}_{5}\left[\mathrm{mg} \cdot \mathrm{l}^{-1}\right]$ & 2.10 & 1.74 & 3.00 & II & 3.95 & 3.11 & 5.00 & III \\
\hline $\mathrm{COD}_{\mathrm{Mn}}\left[\mathrm{mg} \cdot \mathrm{l}^{-1}\right]$ & 10.34 & 8.96 & 16.00 & IV & 11.37 & 10.72 & 15.70 & IV \\
\hline $\mathrm{N}-\mathrm{NH}_{4}^{+}\left[\mathrm{mg} \cdot \mathrm{l}^{-1}\right]$ & 0.17 & 0.18 & 0.26 & ॥ & 0.23 & 0.18 & 0.50 & III \\
\hline $\mathrm{N}-\mathrm{NO}_{3}^{-}\left[\mathrm{mg} \cdot \mathrm{l}^{-1}\right]$ & 1.14 & 1.05 & 1.60 & I & 0.73 & 0.73 & 1.30 & 1 \\
\hline $\mathrm{N}-\mathrm{NO}_{2}^{-}\left[\mathrm{mg} \cdot \mathrm{l}^{-1}\right]$ & 0.03 & 0.02 & 0.04 & 1 & 0.03 & 0.03 & 0.06 & II \\
\hline $\mathrm{P}-\mathrm{PO}_{4}^{3-}\left[\mathrm{mg} \cdot \mathrm{l}^{-1}\right]$ & 0.17 & 0.10 & 0.32 & & 0.11 & 0.11 & 0.15 & \\
\hline $\mathrm{Cl}^{-}\left[\mathrm{mg} \cdot \mathrm{l}^{-1}\right]$ & 26.04 & 26.94 & 33.70 & 1 & 22.37 & 24.82 & 30.00 & । \\
\hline $\mathrm{Mn}\left[\mathrm{mg} \cdot \mathrm{l}^{-1}\right]$ & 0.02 & 0.00 & 0.06 & । & 0.02 & 0.00 & 0.06 & । \\
\hline $\mathrm{Fe}\left[\mathrm{mg} \cdot \mathrm{l}^{-1}\right]$ & 0.30 & 0.19 & 0.50 & $\|$ & 0.17 & 0.17 & 0.30 & 1 \\
\hline $\mathrm{Ca}\left[\mathrm{mg} \cdot \mathrm{l}^{-1}\right]$ & 46.51 & 46.09 & 54.00 & & 36.57 & 35.33 & 44.00 & \\
\hline Acidity $\left[\mathrm{mmol} \cdot \mathrm{l}^{-1}\right]$ & 0.27 & 0.19 & 0.46 & & 0.24 & 0.27 & 0.48 & \\
\hline Alkalinity $\left[\mathrm{mmol} \cdot \mathrm{l}^{-1}\right]$ & 2.03 & 2.09 & 2.70 & & 1.56 & 1.46 & 2.00 & \\
\hline Overall water quality class (OWQC) & & & & IV & & & & IV \\
\hline
\end{tabular}


Table 7 - Material ablation (MA) and SMA in the Mastník catchment

\begin{tabular}{|c|c|c|c|c|}
\hline Parameter & $\mathrm{BOD}_{5}$ & & & \\
\hline Profil & $\begin{array}{c}\text { MA } \\
{\left[\mathrm{kg} \cdot \text { year }^{-1}\right]}\end{array}$ & $\begin{array}{c}\text { SMA } \\
{\left[\mathrm{kg} \cdot \mathrm{km}^{-2} \cdot \text { year }^{-1}\right]}\end{array}$ & $\begin{array}{c}\text { MA } \\
{\left[\mathrm{kg} \cdot \text { year }^{-1}\right]}\end{array}$ & $\begin{array}{c}\text { SMA } \\
{\left[\mathrm{kg} \cdot \mathrm{km}^{-2} \cdot \text { year }^{-1}\right]}\end{array}$ \\
\hline Strašík & $2,499.36$ & 83.31 & $1,388.53$ & 46.28 \\
\hline Rudolec & $14,153.62$ & 104.84 & $3,569.16$ & 26.43 \\
\hline Dubliny & $2,650.84$ & 49.09 & $1,439.03$ & 26.65 \\
\hline Radíč & $130,518.00$ & 486.10 & $148,939.00$ & 554.71 \\
\hline
\end{tabular}

which means in the case of the Křečovický potok sub-catchment, $11 \mathrm{~kg} \cdot \mathrm{km}^{-2} \cdot \mathrm{year}^{-1}$ (Table 7).

The oxygen regime was assessed via the dissolved $\mathrm{O}_{2}$ concentration measurement. As noted above, the availability of oxygen is highly problematic throughout the river basin. The main source of oxygen in the water is reareation. On the other hand, oxygen consumption is observed during the processes of organic substance biochemical degradation - deoxygenation. The oxygen regime is also an indicator of biochemical (BOD) and chemical oxygen consumption (COD). Due to these indicators, the profiles in the catchment area belong in different water-quality categories. The profiles on Sedlecký stream belong to Category III and IV. In both studied profiles, concentration maxima of the $\mathrm{COD}_{\mathrm{Mn}}$ indicator were observed, as well as a maximum for the $\mathrm{BOD}_{5}$ indicator. The values measured in November 2012 were influenced by the emptying of several fishponds into the catchment area. From these ponds, a large amount of organic substances were released. The enhanced values measured in June 2013 are related to the floods at the beginning of the month. These two events also influenced the dependency assessment that, in the Měšetice profile, shows only a minimal decrease in concentration with the

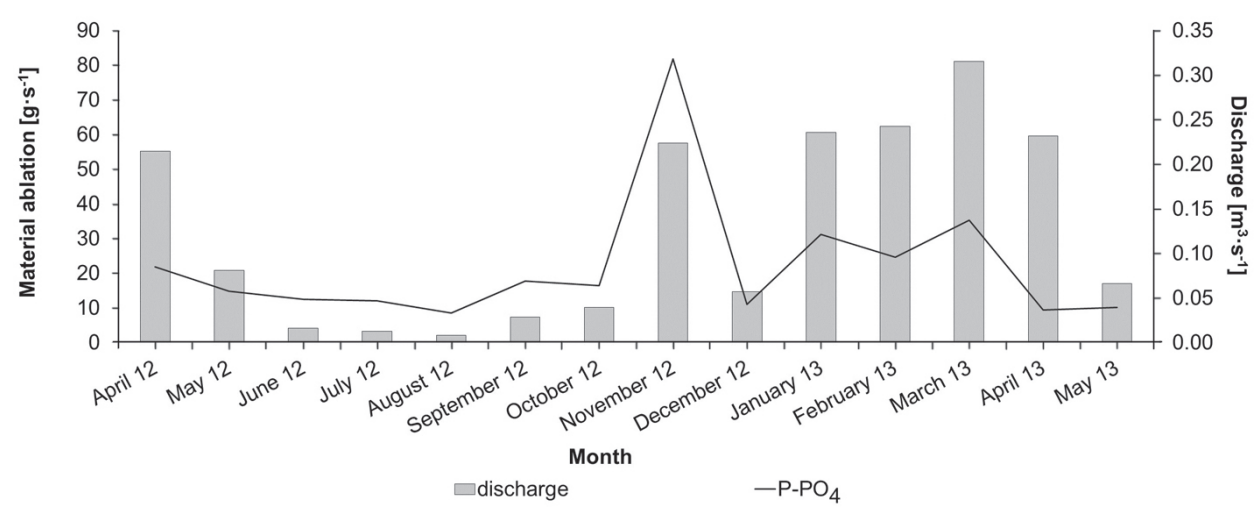

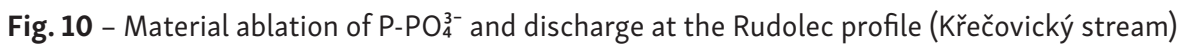




\begin{tabular}{|c|c|c|c|c|}
\hline \multirow{2}{*}{$\begin{array}{l}\text { Parameter } \\
\text { Profil }\end{array}$} & \multicolumn{2}{|c|}{$\mathrm{N}-\mathrm{NH}_{4}^{+}$} & \multicolumn{2}{|c|}{$\mathrm{P}-\mathrm{PO}_{4}^{3-}$} \\
\hline & $\begin{array}{c}\text { MA } \\
{\left[\mathrm{kg} \cdot \text { year }^{-1}\right]}\end{array}$ & $\begin{array}{c}\text { SMA } \\
{\left[\mathrm{kg} \cdot \mathrm{km}^{-2} \cdot \text { year }^{-1}\right]}\end{array}$ & $\begin{array}{c}\text { MA } \\
{\left[\mathrm{kg} \cdot \text { year }^{-1}\right]}\end{array}$ & $\begin{array}{c}\text { SMA } \\
{\left[\mathrm{kg} \cdot \mathrm{km}^{-2} \cdot \text { year }^{-1}\right]}\end{array}$ \\
\hline Strašík & 302.95 & 10.09 & 151.48 & 5.05 \\
\hline Rudolec & $1,025.62$ & 7.59 & $1,476.90$ & 10.94 \\
\hline Dubliny & 214.59 & 3.98 & 214.59 & 3.98 \\
\hline Radičc & $2,473.61$ & 10.22 & $4,703.34$ & 17.51 \\
\hline
\end{tabular}

increase in watercourse discharge volume, as is obvious from Figure 11. A significant decrease in concentrations with increasing flow is ilustrated for both parameters only in the Rudolec profile (Table 5).

\subsection{Summary of results}

Based on the results of our own study, as well as of the official monitoring conducted by state authorities, a final assessment of the studied watercourses water quality in the catchment area has been realised. Figure 11 depicts the watercourse water quality in the Mastník stream catchment area. The evaluation does not necessarily need to be in accordance with reality, as it does not take account of the waterquality changes in the longitudinal profile, or of the step changes. These depend, for example on the location of the wastewater release, the effluent volume etc.

In the entire catchment area, three water-quality categories have been confirmed. The least polluted seems to be the upper part of the Mastník stream up to the confluence with Sedlecký potok. In Figure 12, this part of the watercourse

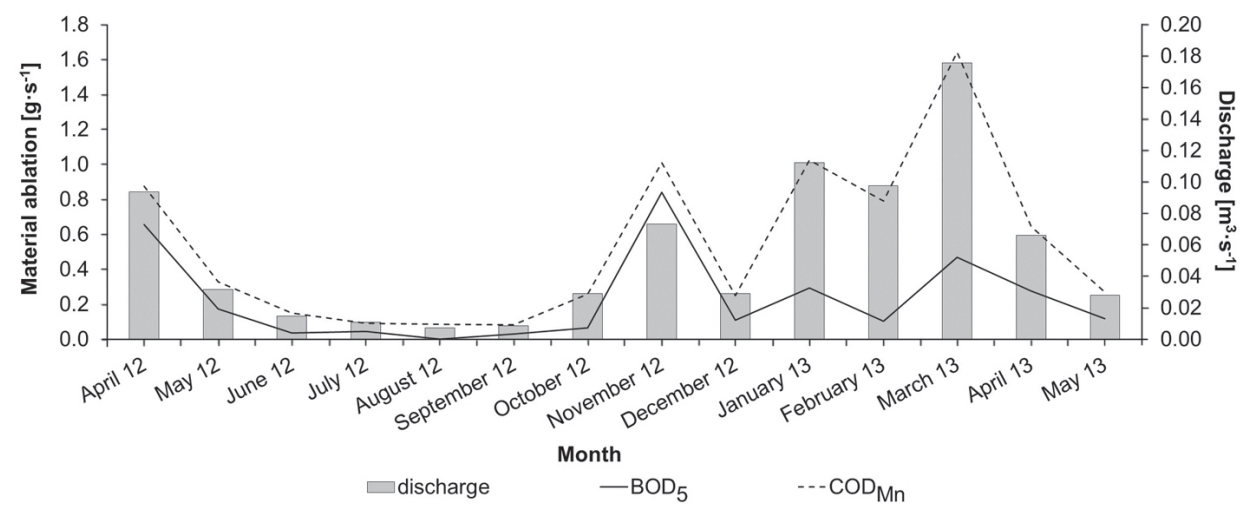

Fig. 11 - Variation of $\mathrm{BOD}_{5}, \mathrm{COD}_{\mathrm{Mn}}$ and discharge in the Měšetice profile (Sedlecký stream) 


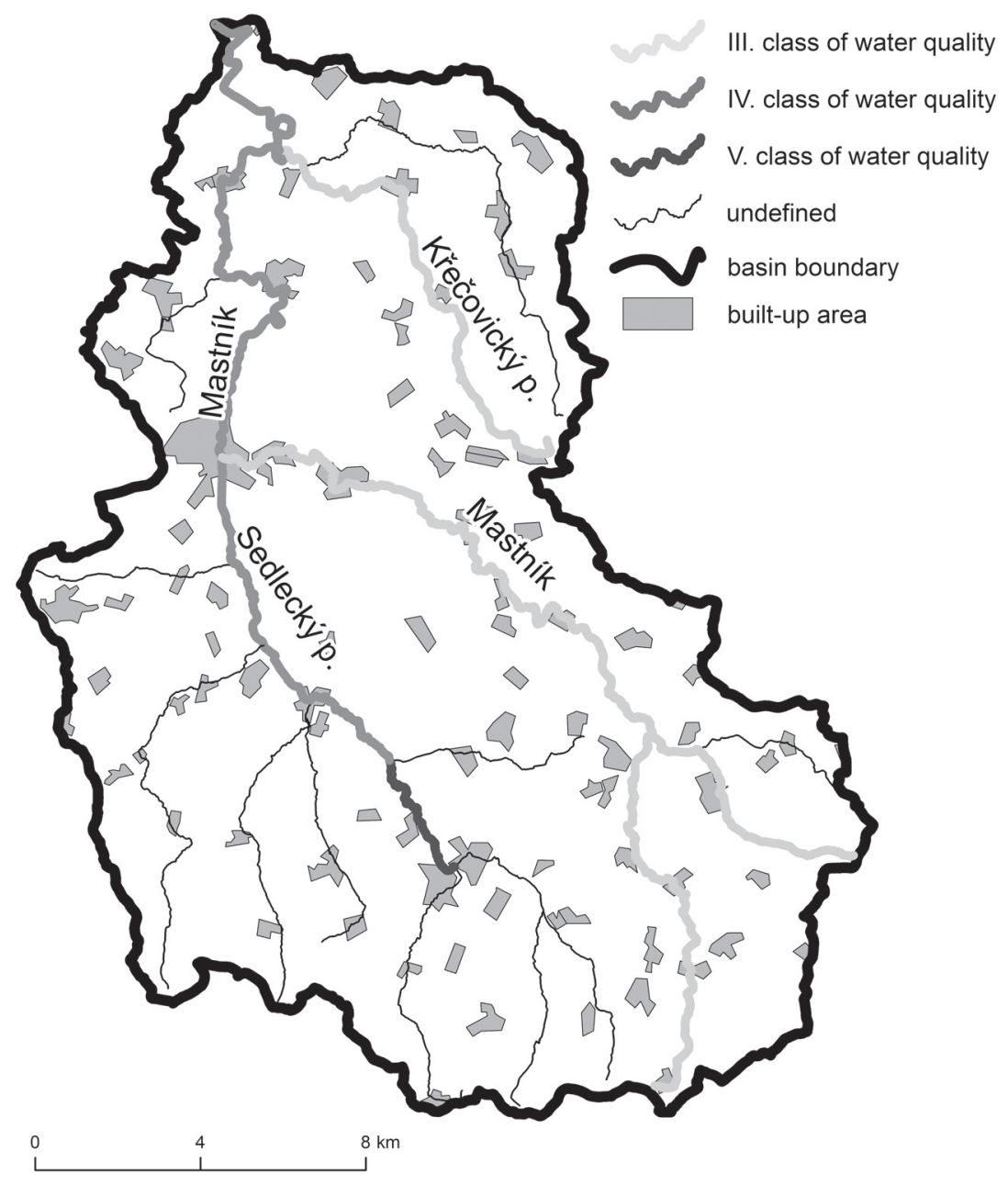

Fig. 12 - Quality of surface waters in the river basin

is depicted as the lightest. The surface water quality was confirmed in the DND, Strašík and Kosova Hora profiles. In this body of water, the largest problem was represented by dissolved $\mathrm{O}_{2}$, organic substances, $\mathrm{P}_{-} \mathrm{PO}_{4}^{3-}$ and TP. The lower part of the Mastník stream watercourse was included in water-quality Category IV. From the confluence with the Sedlecký stream, the Mastník stream was also classified into water-quality Category IV. Due to the effluent in the Sedlecký stream, the quality of the surface water deteriorated significantly. The Sedlecký stream was included in water-quality Category V up to the Měšetice, while the lower part of the watercourse was classified into Category IV. In this catchment subarea, $\mathrm{O}_{2}$, organic substances and phosphorus concentrations were primarily considered 
to be problematic. The Křečovický stream was included in Category III due to the result of SOE monitoring in the Dubliny profile. In this water-body, the watercourses were polluted mostly by organic substances, forms of nitrogene and TP.

Investment in WWTPs in the river basin have not brought any significant positive changes to the overall assessment of surface water quality in the river basin to date. In the Radíc profile, there were no major changes in the classification of water quality between 1996 and 2016, the profile is still Category IV. For a few parameters, however the quality had improved; for example, $\mathrm{BOD}_{5}$ from IV

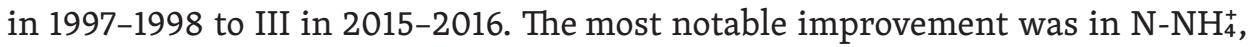
in which there was a shift from Category III to I. In the case of TP, there was no significant improvement in water-quality Category, but the average concentration decreased from 0.69 to $0.24 \mathrm{mg} \cdot \mathrm{l}^{-1}$. There was no change in chlorophyll- $\alpha$, although there was an increase in average surface water temperature, from $9.9^{\circ} \mathrm{C}$ in $1997-1998$ to $11.2^{\circ} \mathrm{C}$ at end of the monitored period in the Radíc profile.

\section{Discussion}

The assessment of surface water quality in this article was based on data from Vltava River Basin Authority monitoring, and was completed in 2012-2013 using profiles obtained for this study. Water analyses were conducted on two separate sites, using various methods, and therefore, the comparison may involve a number of inaccuracies. The evaluation was separate, and only in the results summary is there a complete assessment of the quality of the surface water in the river basin. From this study>s sampling points, one profile was selected to match the position of the SOE profile. This is a profile on Křečovický Creek (Dubliny). Samples were taken several times on the same day, so the difference between the concentrations should have been minimal. For $\mathrm{N}-\mathrm{NH}_{4}^{+}$and $\mathrm{P}_{-} \mathrm{PO}_{4}^{3-}$, the concentrations were slightly overestimated; in the case of $\mathrm{O}_{2}, \mathrm{BOD}_{5}$ and $\mathrm{N}-\mathrm{NO}_{2}^{-}$, the concentrations were slightly underestimated; however, these differences do not affect the resulting water-

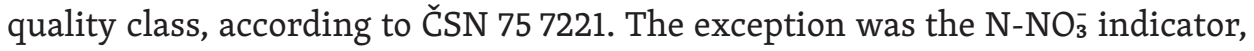
which was based on this study's monitoring, which fell into Category I, whilst, according to the data from Vltava River Basin Authority, this profile should be Category IV. This is due to different methods used in different laboratories. It is also necessary to understand that, for a precise water-quality classification, it is necessary to meet the number of samples and the scope of the indicators included in the so-called basic classification. The second condition was not met by the monitoring from this study (missing information about TP and the saprobe index of macrozoobenthos). That is why this classification is for informational purposes only; however, it was not assumed that, if all the indicators used by the standard were used, the overall rating of the profiles would deteriorate. 
It was also interesting to compare this catchment area with other streams flowing through the countryside. Based on size and the representation of nonirrigated arable land, the Šlapanka basin is very similar, with a flow in the Bohemian-Moravian Highlands, leading to the Sázava River. This river basin also has a similar erosion hazard - $55 \%$ of the area compared to $59 \%$ in the Mastnik basin (LPIS). There are only seven sewage treatment plants in the Šlapanka catchment area, compared to 12 in the Mastnik basin (ISVS-Voda). Therefore, it differs in the amount of emissions discharged into the recipients of the watercourses, but the percentage of connected inhabitants is about $10 \%$ higher than in the Mastnik catchment. When comparing the closing profiles of both flows, similar trends are evident. For example, the downward trend in $\mathrm{N}^{-\mathrm{NO}_{3}^{-}}$concentrations, stagnation and a slight decrease in phosphorus concentrations, $\mathrm{BOD}_{5}$ and COD, and also a problematic indicator in chlorophyll- $\alpha$, the $C 90$ values of which are increasing, pushing the Šlapanka River up to Category V. The average surface water temperatures are also increasing. The rising air temperature and changes in total rainfall are causing water-quality deterioration (Hrdinka et al. 2012). Conversely, no significant problem with dissolved oxygen was found in the Šlapanka basin (unpublished data). On this basis, it can be judged that these river basins behave similarly in many aspects, but that they maintain their regional differences, and the same conclusions cannot be drawn. Of interest, which can also be found in the studied catchment area, is the catchment area of the Mostišter water reservoir in Ždárské vrchy. This river basin is, in the size and extent of the arable land, very similar to the Mastník basin; however, only 9,100 inhabitants live there. In the case of phosphorus and its purification in wastewater to the maximum extent possible, it is concluded that there will be no significant decrease in the concentration of this indicator, the reason being the high percentage of arable land in the catchment area and over-farming of agricultural land (Juráň 2017).

Based on these results, the predominant source of pollution cannot be precisely determined. The problem is still substances originating from point sources, but the influence of wastewater treatment has already been demonstrated to affect certain parameters. It is likely to be argued that the issue of point sources of pollution is abating, as most of the discharged wastewater meets prescribed standards (Jurán 2013). The problem is mainly smaller settlements that do not have their own WWTPs. Significant pollution also derives from agricultural areas, where it is necessary to change the approach to growing crops and farming. The indicators of nutrient concentrations, mainly from area sources, showed no further significant changes during the monitored period. Due to the different meteorological and variable natural conditions in individual years, the identification of surface contamination is rather difficult (Liška et al. 2015). Addressing this issue will be a long process. Limiting eutrophication of the aquatic environment, and reducing 
the water load of nutrients, are two of the main objectives for all developed river basin plans in Europe (Juráň 2013).

\section{Conclusions}

Surface waters in the Mastník stream catchment area are of low quality and in its closing profile, the watercourse has been classified as water-quality Category IV. As for $\mathrm{N}-\mathrm{NO}_{3}^{-}$, a predominance of non-point pollution sources has been confirmed, while in the case of phosphorus, point pollution sources prevailed. The measured values show that organic substance concentrations do not depend on discharge. A not positive finding is the fact that streams do not contain a sufficient amount of dissolved oxygen, which does not allow for self-cleaning. In the studied area, a positive impact of newly constructed WWTPs facilities is obvious. Due to these measures, the communal pollution sources have been curtailed. This manifests itself as a slight decline, or stagnation, in the concentration of some of the studied indicators.

The continually increasing temperature of the surface waters and chlorophyll- $\alpha$ concentration still constitutes a significant problem. An abnormal eutrophication is obvious in the Mastník bay, before it flows into the Vltava River, which poses a major ecological problem. Due to a surface water rise in the Slapy Reservoir, the water flux speed has been limited, and a significant growth of cyanobacteria and algae can be observed in the vegetative season. The growth of cyanobacteria and algae is happening regardless of the decreasing supply of nutrients, especially phosphorus. This increasing concentration is linked primarily to the above-mentioned temperature rise. The eutrophication is also influenced by rural settlement, the communal wastewater from which is channeled directly into the watercource recipient.

It is necessary to be aware that a small change in the surface water quality in the catchment area can also cause a change in the characteristics of the entire watercourse and its environment. In the coming decades, the catchment area will be influenced more by changing climate. The increasing air temperature and changes in the total rainfall will cause water-quality deterioration. To redress the actual situation, it is necessary to begin an overall remediation of the point pollution sources by means of constructing WWTPs. In the case of non-point pollution sources, land consolidation of the agricultural soil could help to solve the problem, if it is directed towards decreasing soil erosion. Research in this river basin is ongoing, in order contribute to our understanding the sources of pollution and the development of water quality within the flow. 


\section{References}

ATLAS KRAJINY ČR (2009). Ministerstvo životního prostředí ČR, Výzkumný ústav Silva Taroucy pro krajinu a okrasné zahradnictví, Praha.

BATES, B.C., KUNDZEWICZ, Z.W., WU, S., PALUTIKOF, J.P., eds. (2008): Climate Change and Water. Technical Paper of the Intergovernmental Panel on Climate Change, IPCC Secretariat, Geneva.

BECKER, A. et al. (2010): Modelling the effects of thermal stratification on the oxygen budget of an impounded river. River research and applications, 26, 572-588.

BOURAOUI, F., GRIZZETI, B. (2014): Modelling mitigation options to reduce diffuse nitrogen water pollution from agriculture. Scinec of The Total Environment, 468-469, 1267-1277.

CORINE Land Cover (2012) - Copernicus Land Monitoring Service: http://www1.cenia.cz/www/ node/595 (11.07.2018).

ČSN 757221 (2017): Jakost vod. Klasifikace jakosti povrchových vod. Úřad pro technickou normalizaci, metrologii a státní zkušebnictví, Praha.

ČSÚ (2011): Městská a obecní statistika, Czech Statistical Office, http://www.czso.cz/lexikon/ mos_vdb.nsf/openkraj?openform\&:cz020 (15.06.2011).

DIAMANTINI, E., LUTZ, S.R. et al. (2017): Driver detection of water quality trends in three large European river basins. Science of the Total Enviroment, 612, 4-62.

GLENDELL, M. et al. (2014): Quantifying the spatial variability of soil physical and chemical properties in relation to mitigation of diffuse water pollution, Geoderma, 214-215, 25-41.

HAYGARTH, P.M., JARVIS S.C., eds. (2002): Agriculture, Hydrology and Water Quality, CABI Publishing.

HRDINKA, T. et al. (2012): Possible impacts of floods and droughts on water quality. Journal of Hydro-enviroment Research,6, 140-150.

JANSKÝ, B. (1982): Vliv plošných zdrojů látek na kvalitu povrchových vod v českém povodí Labe. Disertační práce. PřF UK, Praha.

JANSKÝ, B. (1983): Bedeutung der Frachten aus diffusen Quellen für die Qualität der Oberflächengewässer im tschechischen Einzugsgebiet der Elbe (Labe). AUC-Geographica, 18, 2, 3-25.

JANSKÝ, B. (2002): Changing Water Quality in the Czech Part of the Elbe Catchment Area in the 1990s. Geografie, 107, 2, 74-93.

JANSKÝ, B., JUDOVÁ, P. (2005): Kvalita povrchových vod v povodí řeky Šlapanky: Modelová situace českého venkova. Geografie, 110, 1, 1-13.

JUDOVÁ, P., JANSKÝ, B. (2005): Water quality in rural areas of the Czech Republic: Key study Slapanka River catchment. ELSEVIER, Limnologica, 35, 160-168.

JURÁŇ, S. (2013): Jak dál při hodnocení zátěže ze zdrojů znečištění vod. VTEI, 55, 6, 1-2.

JURÁŇ, S. (2017): Nutrienty ve vodách v povodí Mostiště. VTEI, 59, 5, 14-16.

LANGHAMMER, J. (2009): Kvalita povrchových vod a jejich ochrana. http://www.natur.cuni. cz/ langhamr/ (15.06.2011).

LANGHAMMER, J., KLIMENT, Z. (2006): Změna kvality vody v zemědělských oblastech Česka. Geografie, 111, 2, 168-184.

LANGHAMMER, J., KLIMENT, Z. (2009): Water quality changes in selected rural catchments in the Czech Republic. Ekologia Bratislava 28, 312-332.

LIŠKA, M. et al. (2015): Problematika výskytu pesticidních látek v povrchových vodách vybraných vodárenských zdrojů. Vodní hospodářství, 1,14 .

MRKVA, L. (2013): Kvalita vod v povodí Mastníku a jeho vliv na Slapskou nádrž. Diplomová práce, Katedra fyzické geografie a geoekologie PřF UK, Praha. 
PITTER, P. (2009): Hydrochemie. Vydavatelství VŠCHT, Praha.

PIVOKONSKÝ, M., BENEŠOVÁ, L., JANSKÝ, B. (2001): Evaluation of Water Quality in the River Cidlina. Journal of Hydrology and Hydromechanic, 49, 6, 376-406.

PUNČOCHÁŘ, P., DESORTOVÁ, B. (2003): Informace o stavu trofie našich vodních zdrojů pro veřejnost. SOVAK, 5, 1-3.

TLAPÁK, V., ŠÁLEK, J., LEGÁT, V. (1992): Voda v zemědělské krajině. Zemědělské nakladatelství Brázda, Praha.

VYSKOČ, P. et al. (2014): Postupy hodnocení významnosti zdrojů a cest emisí znečištujících látek do vody. VTEI, 56, 2-6.

ZHOU, P. et al. (2016): New insight into the correlations between land use and water quality in a coastal watershed of China: Does point source pollution weaken it?, Science of The Total Environment, 543, 591-600.

\section{ACKNOWLEDGMENTS}

This work was supported by the Grant Agency of Charles University (project No. 476318) and by Charles University Research Centre program (UNCE/HUM/018). 